\title{
Universiteit
}

Leiden

The Netherlands

\section{The Beginning Of Human Life: Islamic Bioethical Perspectives}

Ghaly, M.M.I.

\section{Citation}

Ghaly, M. M. I. (2012). The Beginning Of Human Life: Islamic Bioethical Perspectives. Zygon: Journal Of Religion And Science, 47(1), 175-213. Retrieved from https://hdl.handle.net/1887/28184

Version: $\quad$ Not Applicable (or Unknown)

License: $\quad$ Leiden University Non-exclusive license

Downloaded from: https://hdl.handle.net/1887/28184

Note: To cite this publication please use the final published version (if applicable). 


\title{
Islam, Paternity, and the Beginning of Life
}

with Mohammed Ghaly, "The Beginning of Human Life: Islamic Bioethical Perspectives"; Ayman Shabana, "Paternity between Law and Biology: The Reconstruction of the Islamic Law of Paternity in the Wake of DNA Testing"

\section{THE BEGINNING OF HUMAN LIFE: ISLAMIC BIOETHICAL PERSPECTIVES}

\author{
by Mohammed Ghaly
}

\begin{abstract}
In January 1985, about 80 Muslim religious scholars and biomedical scientists gathered in a symposium held in Kuwait to discuss the broad question "When does human life begin?" This article argues that this symposium is one of the milestones in the field of contemporary Islamic bioethics and independent legal reasoning $(I j t i h \bar{a} d)$. The proceedings of the symposium, however, escaped the attention of academic researchers. This article is meant to fill in this research lacuna by analyzing the proceedings of this symposium, the relevant subsequent developments, and finally the interplay of Islam and the West as a significant dimension in these discussions.
\end{abstract}

Keywords: bioethics; biotechnology; ijtihad (study of Islamic principles to derive legal opinions from the law); Islam; origin of life; personhood; Qur'an, science; stem cells; theology and science

During the period January $15-17,1985$, the Islamic Organization for Medical Sciences (IOMS) held a symposium in Kuwait with about 80 biomedical scientists and religious scholars participating. The topic of the symposium was "Human Life: Its Beginning and Its End from an Islamic Perspective." This symposium is the second in a series of symposia organized by the IOMS under the title "Islam and the Contemporary Medical Concerns." The full proceedings of this symposium were published in an approximately 700-page volume and divided into two parts: the beginning of human life and the end of human life. This article focuses on the first part where thirteen papers were presented (four by biomedical scientists and nine by religious scholars) in addition to the detailed discussions among the participants whose script was also included in the published volume. The main question handled by these papers was "When does human life begin?" This is in fact one of the fundamental questions

Mohammed Ghaly is Assistant Professor of Islamic Studies, Leiden Institute for Religious Studies, Faculty of Humanities, Leiden University, Matthias de Vrieshof 1, Postbox 9515, 2300 RA Leiden, the Netherlands; email: m.ghaly@hum.leidenuniv.nl. 
in contemporary bioethics whose answer helps formulate standpoints on different bioethical issues such as abortion, embryo research, and stem cell research.

However, this specific question about the beginning of human life from an Islamic perspective could attract the attention of just a few contemporary academic researchers (Aksoy 2007, 89-90; Kurjak et al. 2007, 379; Sachedina 2009, 101-24). These few studies generally adopted a normative approach by giving their own interpretations of a number of scriptural texts relevant to the question about the beginning of human life, which led them to different conclusions. For instance, the interpretation of Aksoy takes the beginning of the eighth week after conception as the starting point of human life, whereas Sachedina argues that human life starts much earlier. As we shall see below, both interpretations were points of extensive debate among the participants in the IOMS symposium. Still, references to the proceedings of this symposium are missing in these studies, and if they ever appear, it is just as incidental references in the context of discussing specific bioethical issues (Atighetchi 2007, 47, 95-96, 107, 123, $167,176)$. A comprehensive analysis of this seminal symposium is, to my knowledge, nonexistent. In order to place these discussions in their broad context, first a note on Islamic independent legal reasoning (Ijtiha $\bar{a} d$ ) and its relevance to contemporary Islamic bioethics is due.

\section{CONTEMPORARY ISLAMIC BIOETHICS AND THE INDEPENDENT LEGAL REASONING (IJTIHĀD)}

It is generally acknowledged that bioethics in Islam is mainly a branch of Islamic law and ethics and thus, contrary to the case in the Western world, not (yet) an independent field of study. Hence, the main contributions in this regard still come from Muslim religious scholars. Missing direct references in the main sources of Islam, especially the Qur'ān (the Holy Scripture of Muslims) and the Sunna (sayings, deeds, and approvals of the Prophet of Islam), the main task of these scholars is to give "an independent legal reasoning or interpretation," known in the Islamic tradition as Ijtihäd of what these sources would imply about different bioethical issues (Ghaly 2010,8).

The proceedings of this symposium show that contemporary Muslim religious scholars do not practice independent legal reasoning (Ijtihād) only when they encounter novel issues on which the main sources of Islam are silent. As we shall see below, references to possible points for determining the beginning of human life are available in both the Qur'ān and the Sunna. Additionally, the bioethical questions relevant to this topic have been extensively dealt with by classical Muslim religious scholars. However, this did not hinder the participants in this symposium from delving into the process of Ijtihäd. This had to do with different factors. 
First of all, the references in the Qur'àn and the Sunna are indecisive concerning the exact starting point of human life and thus remain open for different interpretations (Madhkūr et al. 1985, 253; Yāsīn 1985, 87). Second, the early Muslim religious scholars did not reach consensus about determining the beginning of human life, and their opinions were based not only on understanding the scriptural texts, but also on grasping the scientific and medical information about embryology available in their own time (Madhkūr et al. 1985, 282, 303). Third, the recent scientific and biomedical advancements challenge some of the interpretations advocated by early Muslim religious scholars (Bāșit 1985, 110; 'Ammārī 1985, 174). Thus, the scriptural texts should be reinterpreted and the opinions of early religious scholars should be revised at the hand of the recent scientific discoveries, especially in the field of embryology. Hassān Hathūt (1924-2009), one of the organizers of this symposium, said in this regard, "Some of the points to be presented [in this symposium] are entirely novel, and the early generations of Muslims did not see or write about them.... The problems we discuss here require rational solutions in the first place and textual quotations in the second place. Quoting [early sources] cannot be a valid excuse to circumvent Ijtihād" (Hathūt 1985, 55-56).

However, the organizers of this symposium had in mind specific characteristics for the Ijtihād they call for. First of all, Ijtihād should be seen as an ongoing process. The editorial of the published volume on this symposium stated that $I j t i h \bar{a} d$ should be practiced not only once and for all but on a regular basis so that the participants in this continuing process of Ijtihäd can cope with the recurring magnificent advancements in the field of medical sciences (Madhkūr et al. 1985, 9). The second characteristic is that Ijtihäd should be practiced collectively rather than individually. This refers to what is known in Islamic law as al-Ijtihād al-jamā' $\bar{\imath}$ (collective Ijtiha $\bar{a}$ ), which became in vogue by the second half of the twentieth century, and different institutions, starting by Egypt's Islamic Research Academy ${ }^{1}$ (Majma $^{c}$ al-Bubūth al-Islämiyya) in 1961 were established in order to practice this type of Ijtihād (Sālūs 2008, 10). However, the attention to bioethical issues remained incidental within these institutions, and most of the efforts to tackle these issues remained individual rather than collective. In his opening speech during this symposium, Dr. 'Abd al-Rahmān Al-'Awadīi, the president of the IOMS, lamented the fact that all viewpoints issued on this topic are exclusively based on individual efforts that still miss the required scrutiny. Al-'Awadi added that no single Islamic organization or authority has yet shown interest in adopting the collective approach by holding symposiums where both scientists and religious scholars participate (Madhkūr et al. 1985, 19). In his paper on the beginning of life, Hathūt justified the necessity of adopting this collective approach by arguing that contemporary scientific discoveries became so innovative and groundbreaking and also so full of ramifications that it 
became inevitable for both biomedical scientists and religious scholars to collaborate together in order to handle the bioethical aspects of these discoveries from an Islamic perspective (Hathūt 1985, 55).

On their side, the religious scholars who participated in this symposium approved the suitability of the collective Ijtihäd for approaching such complicated topics. A few days before holding this symposium, the religious scholar Yūsuf al-Qaradāwī wrote in his book on contemporary Ijtiha $\bar{d} d$ about this symposium and commended the idea of involving both biomedical scientists and religious scholars in these bioethical discussions. In the same book, al-Qaradāwī stated that scientific knowledge should be seen as an essential component of the contemporary Ijtih $\bar{a} d$, especially in the field of bioethics (Qaradāwī 1994, 11, 29). In this symposium al-Qaradāwī chaired the last session on determining the beginning of human life. He inaugurated the session by underlying the necessity of the collaboration between the two groups, namely scientists and religious scholars. "A number of our early scholars could master both Islamic law and medicine such as Averroes. However, in our time it is uncommon or even unattainable that someone would do this in this age where having minor specialization is the norm," al-Qaradāwī argued. He added that the religious scholars urgently need the biomedical scientists in order to understand the reality upon which they can draw their conclusions (Madhkūr et al. 1985, 259). This vision of al-Qaradāwi was also shared by the other religious scholars who participated in the symposium. The Tunisian Muhammad Mukhtār al-Salāmī also expressed his appreciation for the IOMS because they promote the collective Ijtiha $\bar{d}$ and try to unify the efforts of both scientists and religious scholars (Salāmī 1985, 111).

Despite the agreement of all participants on the principle that it is necessary and fruitful to discuss these issues together, there was a clear disagreement about the limits of the scientists' roles. Should their roles be restricted to presenting the relevant scientific information? Or is it also possible for them to draw conclusions about the beginning or end of human life from an Islamic perspective? It was clear from the papers presented by the biomedical scientists and the ensuing discussions during the symposium that they aspired for an extended role and not a restricted one. That is why most of them came up with their own vision about the beginning of human life from a religious perspective and also presented their own interpretations for the relevant scriptural texts. Some of the participating religious scholars and also some scientists felt uneasy about this extended role played by some scientists and opined that the role of each group should be restricted to one's own religious or scientific specialization (Madhkūr et al. 1985, 221, 260). In response, the Egyptian physician 'Ișām al-Shirbīnī (1928-2009) stressed that this should not be the case, at least during the phase of deliberations and mutual discussions: "We believe that neither the religious scholar nor the physician has the capacity to examine this issue comprehensively without bilateral discussions between the two groups. 
Further, we are not just physicians. We are Muslim physicians, and the Muslim physician has the right to fathom out the contentions and the [juristic] rulings, to understand the scriptural evidence as far as he can, and also to consult the religious scholar if he does not grasp the ruling" (Madhkūr et al. 1985, 64). The proceedings of this symposium showed that the position advocated by al-Shiribinin, in addition to other biomedical scientists such as Hassān Hathūt and the Egyptian physician who was living in the United States, Ahmad al-Qādī, (1940-2009) had the upper hand. These scientists participated in the process of interpreting the relevant scriptural texts and got into heated debates with the religious scholars not only during the discussions but also in the stage of drafting the final recommendations. For instance, during the final session of the symposium held for discussing the final recommendations, Yūsuf al-Al-Qaraḍāwī spoke to the aforementioned Hassān Hathūt and Aḥmad al-Qāḍ̄ by saying, "I kindly ask Prof. Hassān and brother Dr. al-Qādī not to pressure us [namely religious scholars] more than this. For three days now, they have been trying to force their opinion. We have given some concessions, and now they have to give concessions, too" (Madhkūr et al. 1985, 659).

To conclude, the biomedical scientists in this symposium did not function as just informants for the religious scholars about the required scientific knowledge. They also participated in the Ijtihäd process as equal partners and tried to give their opinion from a religious perspective. This indicates an important development in Islamic thought where Ijtihäd was usually seen as the exclusive right of the religious scholars or those who master the Islamic religious sciences (Sānū 2006, 21-22).

\section{When Does Human Life Begin? A Variety of Islamic PERSPECTIVES}

The proceedings of this symposium show that there is a great variety of opinions about the exact beginning of human life from an Islamic perspective. Some of these opinions remained marginal during the symposium and were completely ignored in the final recommendations as well. For instance, the Egyptian dermatologist Ibrāhīm al-Ṣayyād opined that the Prophet of Islam gave a definition for human life in the tradition related around the incident of the cat when he was asked by the Companions whether God would reward people for taking care of animals. The response of the Prophet was that taking care of every creature with humid liver (kabid ratba), and in another version of the tradition warm liver (kabid harrāa), would be rewarded by God. Al-Ṣayyād argued that this tradition speaks about living creatures, and the sign of being alive, as given by the Prophet, is having a humid and warm liver with a functioning blood circulation system (Madhkūr et al. 1985, 295). None of the participants further commented either positively or negatively on al-Ṣayyād's understanding of the tradition. Only Yūsuf al-Al-Qaraḍāwī 
gave two comments, none of which had to do with accepting or refusing al-Sayyād's interpretation. The first comment was about the authenticity of the tradition by saying that it is authentic. The second comment was correcting the context of the tradition. Al-Qaradāwī said that the tradition was related to the incident of the dog and not the cat (Madhkūr et al. 1985, 297).

Beyond al-Ṣayyād's contention, the rest of the participants in this symposium can be divided into two main positions advocating either conception or the moment of soul-breathing as the determinant for the beginning of human life. The advocates of each position had internal disagreements about some minute details, which will be elaborated below. The arguments used by each group were not only theological or religious in nature. The participants gave considerable attention to biomedical, scientific, and rational arguments as well.

\section{The First Position: Conception Is the Starting Point of HUMAN LiFE}

The main thesis of this position is that human life starts by conception, or in other words, when the ovum of the mother gets fertilized by the sperm of the father. The main advocates of this position included different

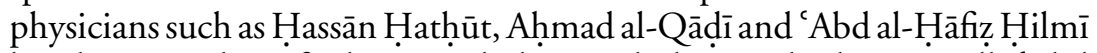
besides a number of religious scholars, including Badr al-Mutawalli ' $\mathrm{c} A \mathrm{bd}$ al-Bāṣiț, Muhammad Mukhtār al-Salāmī, Muhammad 'Abd al-Hādī Abū Rīda, Ạhmad al-Ghandūr, and 'Abd al-Qādir bin Muhammad al-'Ammārī.

As noted earlier, the advocates of each position had some internally nuanced differences. For instance, unlike Hathūt, who opined that human life starts at the very moment of conception, Badr al-Mutawallī 'Abd alBāsit added to fertilization as criterion the phrase "and that it [the fertilized ovum] has got settled in the womb (wa istigrār dhälik fi al-rahim)," which means that human life would start a bit later than what Hathūt contended (Hathūt 1985, 59; Bāṣiṭ 1985, 109). The difference between the two standpoints within this position got clear at the hand of the practical question raised by a number of physicians about using an intrauterine device (IUD) that is believed to restrain the already fertilized ovum from being implanted in the wall of the uterus. Is using the IUD permissible from the viewpoint of those who opined that human life starts at the very moment of conception (Madhkūr et al. 1985, 280-81, 290, 319)? In response, the two main religious scholars supporting this posiiton, Shaykh 'Abd al-Bāṣit and Shaykh al-Salāmī, said that life should be protected once the fertilized ovum gets settled in the womb and not before. Shaykh alQaradāwī, from the second position, interpreted their statement by saying that they mean that life before the settlement of the fertilized ovum in the uterus has no dignity and hence there is no harm if the IUD threw it 
away (Madhkūr et al. 1985, 323-24). The zoologist 'Abd al-Hāfiz Hilmī and the physician Ahmad al-Qādī were first inclined to the viewpoint advocated by Dr. Hathūt that stated that human life starts by the very moment of conception. After the arguments and counterarguments on this practical issue, they changed their mind and started to believe that human life would start a couple of days after the process of fertilization when the fertilized ova get settled in the womb (Madhkūr et al. 1985, 305, 324). Dr. Hathūt remained, however, steadfastly advocating that human life starts by conception. He said that the fertilized ovum takes about seven days before it gets settled in the uterus. "Of course, I do not think that any of us would say that the soul gets breathed on this seventh day!" Hathūt argued. Thus, the IUD should be considered as a forbidden abortifacient and not as a permissible contraceptive (Madhkūr et al. 1985, 326-27). Beyond this disagreement on the religious ruling concerning the IUD, the arguments of the advocates of this position did not differentiate between conception and implantation as a starting point for human life.

Before delving into the scientific arguments advanced by the advocates of this position, an analytical remark about this position is due. One of the main characteristics of this position is the general conviction that biomedical and scientific knowledge should be given precedence over the opinions expressed by classical Muslim religious scholars. Further, this scientific knowledge should be the dominant factor when we choose one of the possible interpretations for the scriptural texts. For instance, Dr. Hathūt referred to the opinion within the Hanbali school of law that it is permissible to get rid of the embryo before breathing the soul. Most probably, Hathūt argued, they based this opinion on their belief that the embryo before the soul-breathing stage is not living. In the light of modern medical knowledge, such an opinion cannot be accepted (Madhkūr et al. 1985, 303). The Tunisian religious scholar Mukhtār al-Salāmī said that this critical approach was also present among some classical Muslim scholars who managed to master both medicine and Islamic law such as al-Rāzì. Al-Rāzī criticized a number of religious scholars from the Mālikī school who opined that some of the newborn babies who die shortly after delivery can be considered as nonliving even if they could have suckled once or twice from their mothers' breasts. Al-Rāzī said that suckling, from a scientific point of view, can never be done by a dead person (Madhkūr et al. 1985, 231). As for the interpretation of the scriptural texts, it was clear that different advocates of this position were convinced that the apparent meaning (al-zāhir) of a scriptural text should be abandoned as long as it contradicts scientific knowledge, and preference should be given to the metaphorical interpretation ( $\left.t a^{\prime} w \bar{\imath} l\right)$. The Kuwaiti religious scholar 'Abd Allāh Muhammad 'Abd Allāh referred to the thirteenthcentury religious scholar ' Umar b. Muhammad al-Sunāmī who adopted this approach. Al-Sunāmī made reference to the tradition of Ibn Mas ${ }^{c} \bar{u} d$ 
(see the Appendix), which implies that breathing the soul in the embryo takes place after 120 days. Al-Sunāmī spoke about the opposition of his contemporary physicians who argued that the purport of this Prophetic tradition cannot be universally applied to every case of pregnancy. Their opposition is based on medical practice whose denial, al-Sunāmī added, is tantamount to denying facts. Al-Sunāmī tried to reconcile between the text of the tradition and the medical knowledge of his time by saying that the opening sentence in the tradition "The creation of one of you (ahadakum) is put together in his mother's womb in 40 days" indicates that its meaning is specific and not general. The grammatical structure "one of you" (ahadakum) does not necessarily mean everyone but possibly just one specific person. This is also the case in other Qur'anic verses that used the same structure in reference to a specific person and not to everyone such as "Now send one of you (ahadakum) with this money of yours to the town" (18:19) ('Abd Allāh 1985, 166-67). Further, we shall see below how the proponents of this position exerted arduous efforts in order to reconcile the Prophetic traditions on this issue, especially the tradition of Ibn Mas ${ }^{c}$ ud (see the Appendix) with the purport of the scientific arguments as outlined by Dr. Hathūt.

As for the scientific arguments advanced by the advocates of this position, Hathūt argued that embryogenesis is an extremely gradual process characterized by continuity and harmony, and thus there is no way to pinpoint a specific moment and claim that here is the beginning of human life. That is why, Hathūt added, the beginning of this life should be counted from the earliest stage in which the following five conditions are all applicable to a being: (1) the being has a clear and well-known start; (2) he has the potential to grow as long as he has not been deprived of the causes of growth; (3) his growth would result in a human being as fetus, neonate, child, boy, young man, adult, old man, and so forth; (4) this being in an earlier stage cannot grow to become a human being; and (5) the being carries the full genetic code of the human race in general and of this being in specific that distinguishes him from all others throughout the ages. To Hathūt, all these conditions are only applicable to the fertilized ovum and thus not to any of the stages before or after conception (Hathūt 1985, 58-59). In reference to the other position, which takes the moment of soul-breathing as the beginning of human life, Hathūt said that breathing the soul is from the perspective of medical sciences a purely metaphysical concept that belongs to the ghaybiyya thus cannot be examined. Hence, any bid to claim a link between this religious concept and specific neurobehavioral developments that can be observed by science, Hathūt argued, is unfortunately a matter of folklore rather than a scientifically grounded argumentation. Hathūt also expressed his dissatisfaction with calling life prior to the moment of soul-breathing as vegetative or animal life in contrast to human life that would then start 
after the soul-breathing. He said that human life cannot be compared to that of plants that, unlike human beings, have neither active motor systems nor nervous systems. Additionally, plants nourish themselves with light, absorb carbon dioxide, and discharge oxygen. As for comparing human life to animal life, Hathūt said that the Darwinists might be happy when we state that one of the stages of human embryo is an animal life, but we would not say that (Hathūt 1985, 57). Dr. Aḥmad al-Qādī added that the fertilized ovum would never develop into an animal but just a human being (Madhkūr et al. 1985, 206).

Concerning the religious arguments, the advocates of this position made use of different Qur'anic verses, Prophetic traditions, practical rulings in Islamic law, and the opinions adopted by early authoritative Muslim religious scholars.

One of the Qur'anic verses quoted to support this position is "Verily We created Man (insān) from a drop (nutfa) of mingled sperm" (76:02). So, the Qur'ān used the term insān (man or human being) to speak about the nutfa, which is the earliest stage in pregnancy as outlined in different Qur'anic verses (Madhkūr et al. 1985, 218). The other verse reads "And when you are embryos (ajinna) in the wombs of your mothers" (53:32). Dr. Hathūt wondered, who are "you" in this verse? It is you and me; the human being, he replied. He wants to conclude that the Qur'ān speaks about human life even in the stage of the embryo (Madhkūr et al. 1985, 303).

As for the Prophetic traditions, the advocates of this position gave comments on the two traditions, which were central in the discussions (see the Appendix). Both traditions speak about an angel whom God entrusts with specific tasks concerning the future of the embryo such as determining the sex and age and breathing the soul. The advocates of this position argued that the texts of these two traditions cannot be taken at face value in order to claim that human life starts after 40 or 120 days of pregnancy. Beyond breathing the soul, which cannot be examined on scientific grounds, modern science shows that other tasks mentioned in these traditions cannot be executed on any of these two dates. For instance, the sex of the to-be-born baby gets determined by the moment of the union between the male sperm and the female ovum and thus not after 40 or 120 days of pregnancy but much earlier. Therefore, the text should be metaphorically interpreted so that it will not contradict science. Hathūt's proposed interpretation was that the angel on that day ( 40 or 120) does not determine the sex of the to-be-born, but just asks God to know from Him what had already been destined in this respect (Hathūt 1985, 58; Madhkūr et al. 1985, 298). As for the three stages mentioned in the tradition of Ibn Mas' ${ }^{\mathrm{u}} \mathrm{d}$ (see the Appendix) and that each of which would take 40 days, Muhammad 'Abd al-Hādī Abū Rīda (1909-1990), the late professor of Islamic philosophy, said that metaphorical interpretation $\left(t a^{\prime} w \bar{\imath} l\right)$ should 
be used. Each of these stages should be understood just as a stage in the process of embryonic development and not that 'alaqa or nutfa lasts for 40 days. That is because adopting the literal interpretation in this regard would collide with the medical reality (Madhkūr et al. 1985, 225-26). As for breathing the soul specifically, the argument was that the soulbreathing is just an incident that takes place within the life of the embryo and does not necessarily mark the beginning of human life (Hathūt 1985, 57-58). The Yemeni religious scholar 'Abd al-Qādir bin Muhammad al'Ammārī said that this interpretation is not necessarily contradictory to the tradition of Ibn Mas ${ }^{c} \bar{u}$, which, at first sight, indicates that there are three consecutive stages in the pregnancy, each of which takes 40 days, and after this the soul gets breathed by the angel. The text of the tradition divides between each stage with the conjunction "then," in Arabic thumma, which is usually seen as a coordinating conjunction and thus implies that these stages are chronologically ordered. This is one of the grammatical functions of "then" (thumma) in the Arabic language, but it is not necessarily its only function, al-'Ammārī argued. For instance, this conjunction can sometimes be used as a synonym for the conjunction "and" in Arabic "wa" and in this case does not imply any chronological order. Al- 'Ammārī argued that "then" (thumma) in the tradition of Ibn Mas' ūd can be best interpreted as "and" $(w a)$. For instance, when reviewing the same stages mentioned in the tradition of Ibn Mas' ūd, the Qur'ān sometimes uses the conjunction "then" (thumma) (22:05) and sometimes another conjunction, namely $f a$ (also usually translated in English as "and") (23:13). This means that "then" (thumma) is not meant here to convey a specific chronological order. According to this reading, there can be an overlap between the stages mentioned in the Prophetic traditions and that these stages including breathing the soul can be repeated three times, each time continues for 40 days. In this way, the tradition of Ibn Mas ${ }^{\mathrm{u}} \mathrm{u}$ can also be reconciled with the other relevant Prophetic traditions, especially the tradition of Hudhayfa (see the Appendix) (Ammārī 1985, 172-73). Dr. al-Shirbīnī was not satisfied with al- 'Ammārīs interpretation of the conjunction "then" (thumma). He said that it is true that sometimes this conjunction does not imply a chronological order between two incidents. However, this is not applicable to a sentence which, starts with the verb "start/begin" and the conjunction "then" (thumma) comes afterward. This is exactly the case of the Qur'anic verses that spoke about the creation of the human being, "He began the creation of man with clay. Then (thumma) He made his progeny from a draught of despised fluid. Then (thumma) He fashioned him in due proportion and breathed into him of His Spirit" (32:07-09) (Madhkūr et al. 1985, 203).

The advocates of this position were sometimes accused of being influenced by the materialists who denies the existence of the soul at all. That is because they do not give any special consideration to the incident 
of the soul-breathing as a crucial point in the gestational development. For instance, the Jordanian religious scholar Muhammad Na ìm Yasin, who is an advocate of the second position, argued that calling life before breathing the soul an animal life would not make Darwin happy. What would make Darwin happy is to set the soul aside and make it a metaphysical concept with no touchable influence in human life (Madhkūr et al. 1985, 222). In response, al-Qādī said that the proponents of this position stress that human life starts by the moment of conception not because they do not give special consideration to the soul. On the contrary, al-Qàdī added, they adopted this opinion in order to save this human being, including his soul, which would seem less valuable if we said that human life starts on a later date (Madhkūr et al. 1985, 269, 288).

One of the arguments advanced by the proponents of this position is the list of practical rulings in Islamic law, which kept pregnancy into consideration without differentiating between the period before or after breathing the soul. For instance, if a pregnant woman was sentenced to death, the death penalty should be postponed until she delivers her baby. The fact that this postponement should take place anyhow whether this pregnancy is still in the beginning or in its final stage means that Islamic law sees that there is life that should be respected. Otherwise, why would the death penalty be postponed then (Hathūt 1985, 59-60; Bāṣit 1985, 109; Salāmī 1985, 115-21; Madhkūr et al. 1985, 219-20, 303)?

The advocates of this position also stressed that their opinion, although based on modern science, is not an innovation within Islamic law and that early Muslim jurists advocated this opinion. The main classical scholar quoted by the advocates of this position is the well-known Muslim jurist, theologian, and mystic Abū Hāmid al-Ghazālī (d. 111). According to this position, al-Ghazālī also opined that life should be respected from the beginning of pregnancy and thus any offence against this life should be punishable from an Islamic perspective. The Mālikī school of law also opined that the existence of life, which should be respected from a religious perspective, starts from the date of fertilization and any offence against this being is prohibited. As for the contention of other classical religious scholars that the fertilized ovum can be damaged before the stage of soul-breathing, the advocates of this position argued that such an opinion is not valid anymore now. These classical scholars based their contention on the belief that a fertilized ovum before breathing the soul can be just congealed blood. However, with the help of available scientific tools, we can be sure if there is pregnancy or not. Further, it is scientifically proven that there is life before the moment of breathing the soul, and thus it is clear that the soul does not get breathed into a dead fetus (Hathūt 1985, 59; Bāṣiṭ 1985, 110; Salāmī 1985, 119).

The slippery slope argument was also advanced by the advocates of this position. In Islamic law, the legal term of this argument is sadd 
al-dhara $\bar{a} i$, which literally means "blocking the means" and as a technical term indicates "blocking the means to evil" (Kamali 2003, 397). Different voices within this tradition warned that determining the beginning of human life by a date later than the moment of conception, different evils would ensue. For instance, people would be very lax about perpetrating abortion before the date seen to mark the beginning of human life. Dr. al-Qādī spoke about his own experience in the United States where more than one million abortions are reported on an annual basis, and many of these abortions take place even after 40 or 120 days. He added that this is exactly what would happen if we ratified, for instance, the opinion stating that human life starts after 40 days. That is because women usually make mistakes about determining the date of the last menstrual period from which the gestational age gets calculated (Madhkūr et al. 1985, 298). The Tunisian religious scholar Muhammad Mukhtār al-Salāmī referred to another possible evil, namely promoting birth control in the third world countries. Terminating pregnancy on purpose by means of medical intervention, al-Salāmī argued, is prohibited from an Islamic perspective unless the pregnancy would jeopardize the mother's life or the embryo gets deformed. Astonishingly enough, al-Salāmī wondered, the Western countries are eagerly interested in controlling the birth rates in the third world instead of thinking, for instance, of exploiting the natural resources. Al-Salāmī appended his paper presented to the symposium with the text of an article published by the French newspaper Le Mond in December 1984. The article spoke about developing abortifacient known as RU486 (later known as mifepristone) that can terminate pregnancy without surgical operation even after 7 weeks of pregnancy. The article added that the researchers argued that this abortifacient would be the optimum way for women in the third world countries to do birth control because it does not necessitate the availability of advanced medical infrastructure (Salāmī 1985, 121-22; Madhkūr et al. 1985, 287-88, 302).

\section{The Second Position: Breathing the Soul Is the Starting POINT OF HUMAN LifE}

The main thesis of this position is that human life starts by breathing the soul, which happens later than the moment of conception. This position was advocated by different religious scholars, including Yūsuf al-Al-Qaraḍāwī, Muhạmmad Na īm Yasīn, Muhammad Fawzī Fayḍ Allāh,

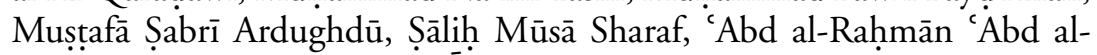
Khăliq, and 'Abd Allāh al- - $^{\prime} \dot{s} \bar{s}$, in addition to a number physicians, including 'Iṣām al-Shiribīnī, Aḥmad Shawqī Ibrāhīm, and 'Abd Allāh Bāsalāma.

Despite their agreement on recognizing the soul-breathing as the starting point of human life, the advocates of this position disagreed on how to 
measure this stage from a scientific point of view and also on the supposed date on which the soul-breathing takes place.

This position also made use of different arguments, some of which were scientific in nature, whereas the other arguments had to do with religious aspects such as Qur'anic verses, Prophetic traditions, and early authorities in Islamic law. Before delving into the details of these arguments, an analytical remark is due about the main methodological differences between this position and the previous one concerning the position and the value of medical and scientific knowledge when dealing with scriptural texts.

The first position believed that all relevant scriptural texts are in principle open for different interpretations and none of these interpretations is definitive (qat $\left.{ }^{(} \bar{\imath}\right)$. So they had no problem to apply the tools of metaphorical interpretation ( $\left.t a^{\prime} w \bar{\imath} l\right)$ as long as this will lead to a conclusion that is compatible with medical and scientific knowledge. This approach did not appeal to some of the advocates of the second position. The strongest opposition came from the Kuwaiti religious scholar 'Abd al-Rahmān 'Abd al-Khāliq, who accused the first position and its advocates, including Dr. Hathūt, of trying to cross out the Qur'anic verses and the Prophetic traditions from the discussions and claim that these texts are something metaphysical that cannot be examined by science. He argued further that the relevant scriptural texts on this issue are definitive and they are not open for different interpretations. For instance, when the Prophet says that the fluid-drop (nutfa) stage continues for 40 days, we cannot interpret this text metaphorically and say that this means thirty-nine. Such a metaphorical interpretation is not a religious paradox, but a religious sin (Madhkūr et al. 1985, 241-43). Further, even if the text is open for different interpretations, then recourse should be made to the apparent meaning ( $z \bar{a} h i r)$ of the text, and available scientific knowledge does not justify applying the tools of metaphorical interpretation. This scientific knowledge, especially the recently developed science of embryology, is speculative $(z a n n \bar{\imath})$ and undergoes recurrent revisions and amendments every now and then, whereas the Qur'anic verses and the Prophetic traditions are firmly established and cannot change anymore (Ibrāhīm 1985, 204; Madhkūr et al. 1985, 242, 272-73). That is why, Dr. Aḥmad Shawqī Ibrāhīm argued, whenever a scientific opinion or discovery challenges the Qur'ann or the Sunna, then it means that this opinion is wrong and one day people will find this out (Ibrāhìm 1985, 204). On his side, Dr. Hathūt from the other position was unhappy with this criticism and said that none of the participants in this symposium would have doubts about this fact. To him, the main issue is not to compare between science and religion to see which one would give more certainty. The main issue is that there are scriptural texts that are open for different interpretations, and science might sustain one of these interpretations. Why should we 
confine ourselves to one specific interpretation as long as there are other alternatives, Hathūt wondered (Madhkūr et al. 1985, 254-55).

As for the scientific arguments, the proponents of this position opined that the incident of breathing the soul can be detected now by means of reliable scientific tools. The Egyptian neurologist Mukhtār al-Mahdī said that determining the beginning of human life was a mission impossible in early times because breathing the soul was a metaphysical issue with no scientific equivalent. This situation has drastically changed, especially in the last years where the different embryonic developments can be followed and in some cases even controlled and manipulated. Thanks to these modern scientific advancements, a specific embryonic development can now be pinpointed and state that it is an indication of breathing the soul and thus the beginning of human life (Mahdi 1985, 64-65). With the exception of the aforementioned opinion expressed by Ibrāhīm al-Ṣayyād that functioning liver and active blood circulation mark the soul-breathing stage, the physicians who supported this position opined that development of the nervous system and especially the brain is the scientific sign that ushers the soul-breathing stage (Mahdī 1985, 67-69; Ibrāhīm 1985, 75; Bāsalāma 1985, 79, 81).

As for the five conditions outlined by Hathūt, whose fulfillment by the moment of conception would indicate the beginning of human life, the advocates of this position raised questions about the validity of the third condition, namely the fertilized ovum would result in a human being. They said that it is not necessary that the union of a male sperm and a female ovum would finally produce a human being. Sometimes this union results in molar pregnancy, which is in fact clusters of cells that have life and has also the capacity to proliferate inside the uterus. The life of these cells endangers the mother's life and thus must be disposed of in order to rescue the life of the mother (Bāsalāma 1985, 77; Madhkūr et al. 1985, 215). Shaykh al-Salāmī replied to this argument by saying that rulings in Islamic law can be based on rules that are not applicable to every relevant single case but just to the majority of them. At the end every rule should have its own exceptions, al-Salāmī concluded (Madhkūr et al. 1985, 302). Dr. Mukhtār al-Mahdī raised another question about the applicability of these conditions to the case of twins. In this case, the fertilized ovum splits into a number of cells, each of which produces a distinct embryo, so when did the human life of this twin start? Was this when the ovum got fertilized or when the ovum split into cells? (Mahdī 1985, 63). In response to al-Mahdī’s question, Dr. Hathūt said that this question is based on perceiving life as something material and divisible, so when the fertilized ovum splits into twins, it means that each of the two would have half of the life of the fertilized ovum. The entity of life is unknown, Hathūt argued, and thus cannot be approached through our common materialistic notions. To Hathūt, religion can also help understanding the phenomenon of twins. One would then say the ovum destined by God to produce 
twins was originally provided with two lives (Hathūt 1985, 60). Instead of these five conditions that looked controversial from the perspective of this position, Dr. al-Mahdī spoke about five embryonic developments taking place during the twelfth week of pregnancy that all indicate the emergence of a distinct human being, namely (1) the movements of the fetus start to become complex and harmonious rather than being hectic, (2) the emergence of breathing-like movements that are not meant for obtaining oxygen because the lungs do not work anyhow during pregnancy. However, these movements are strong indicators that the brainstem started to work because respiratory control is one of its functions, (3) the fetus experiences consequent and regular activity-rest rhythms where periods of locomotor activity get usually followed by periods of rest and sleep, (4) some research papers showed that electrical signals produced by the fetal brain emerge in the twelfth week and can also be measured. These signals indicate that both the cerebral cortex and the cerebral hemispheres started to work, and (5) the onset of fetal movements, which do not have a sudden, jerky, or spastic quality and thus convey new significance. These new movements are responses to exterior alerts such as these of the Doppler ultrasound while moving on the belly of the pregnant woman. This means that specific brain centers have caused these movements and started to make the fetus aware of anything abnormal that might happen around him and thus be able to distinguish these abnormal exterior alerts from the normal sounds and movements such as the mother's heartbeat. Al-Mahdī added that these new developments that take place in the twelfth week and that also coincide with the fact that the brain gets fully shaped and starts to function represent a turning point in the fetal development (Mahdī 1985, 68-69). On his side, the Saudi gynecologist 'Abd Allāh Husayn Bāsalāma stressed that the existence of a fully developed and sound brain is an essential condition to state that the fetus has a human life, especially bearing in mind that some religious scholars said that the place of the soul is the brain (Bāsalāma 1985, 81; Madhkūr et al. 1985, 215). From the other camp, Dr. Hathūt objected to associating the beginning of human life with the functionality of the nervous system and found this very unconvincing. First of all, Hathūt argued, the existence of the nervous system precedes the moment of soul-breathing and does not get fully developed even by the moment of birth. Additionally, the newborn calf can run directly, whereas the newborn human being cannot do this for a long time (Hathūt 1985, 58). Dr. alQādī also objected to using the full development of the brain as a marker for the beginning of human life. "We know that the function of the brain does not come to perfection either in the fourth month or even in the ninth month of the fetal age," al-Qādī argued (Madhkūr et al. 1985, 209). In response, Dr. al-Mahdī said that his criterion for determining the beginning of human life—namely, the brain gets fully shaped—is a new scientific point of view and that "brain gets fully shaped" does not mean 
literally the maturation of the brain but just that it starts functioning in the twelfth week of pregnancy (Madhkūr et al. 1985, 210).

The physicians advocating this position also made use of a well-known rule in Islamic jurisprudence known as qiyass (analogical reasoning) but they applied it to science rather than to religion. As a legal term in Islamic law, qiyās means the extension of a religious ruling $(\mathrm{hukm})$ from an original case (asl), which is regulated by a scriptural text, to a new case $\left(\mathrm{far}^{\circ}\right)$ because the latter has the same effective cause ( ${ }^{\text {illla) }}$ ) as the former (Kamali 2003, 264). The original case here is that brain death marks the end of human life. The new case in this regard is that the birth of the brain marks the beginning of human life. The advocates of this position argued that as long as there is no disagreement among scientists about the original case, then the new case should also be accepted by means of analogy because of the commonality of the effective cause, namely, the central role of brain in determining the nature of human life (Bāsalāma 1985, 81; Mahdī 1985, 69). Dr. al-Qādī did not agree with applying qiyās in this regard and argued that there is a discrepancy between the two cases. After brain death, the life of some cells can be sustained with the help of nutrition and medical care, but they will not constitute a human being in the future. This is not the case with the fertilized ovum that will result in a human being as long as it receives the due nutrition and care even if it was taken away from the body of the pregnant woman and got implanted in another woman's uterus (Madhkūr et al. 1985, 207). Dr. al-Mahdī commented very briefly on al-Qādî̀s criticism by saying that he did not mean comparing cells but tissues (Madhkūr et al. 1985, 210).

The advocates of this position tried to reconcile the scientific vision, which ensures the existence of different symptoms of life before breathing the soul with the traditional religious view that makes breathing the soul as the marker of the beginning of human life. They opined that there is life prior to breathing the soul but not yet a buman life. They gave different labels to life in this early stage of pregnancy such as vegetative, animal, cellular, and organic life (Mahdī 1985, 63; Ibrāhīm 1985, 74-75; Yāsinn 1985, 96). In this respect, the Egyptian surgeon Ahmad Shawqī Ibrāhīm commented on Hathūt's objection that naming life before the soul-breathing an animal life implies that the embryo goes through an animal-like stage and thus partially agrees with the Darwinists. Dr. Ibrāhīm said that naming life in this stage an animal life does not mean that we believe that the embryonic cell in this stage is a cell of an animal. Ibrāhīm also said that the Darwinists are not completely wrong because there is a certain degree of evolution in the creation as indicated by different references in the Qur'ān and the Sunna. However, these references support the idea that each species undergoes evolution separately, but not that all species descends from a common ancestor (Madhkūr et al. 1985, 204).

The sharp disagreements among the scientists participating in this symposium on almost every point were disappointing for different 
religious scholars. For instance, the Yemeni religious scholar 'Abd al-Qādir al-'Ammārī said that physicians should be blamed for disagreeing with each other because, unlike the religious scholars, they have plenty of medical and scientific tools to settle these disagreements (Madhkūr et al. 1985, 221). The same holds true for the ex-Minister of Religious Affairs in Egypt, Ibrāhīm al-Dasūqī, who got confused because of these disagreements (Madhkūr et al. 1985, 225, 250), and the Jordanian religious scholar Muhammad $\mathrm{Na}^{\text {cimm }}$ Yasin, who could not find clear answers from the physicians about when the formation of the brain starts and when it comes to completion (Madhkūr et al. 1985, 223). Consequently, the general impression especially among the advocates of this position, including even a number of physicians, is that biomedical knowledge cannot give a decisive answer to the question "When does human life begin?" The answer should instead be sought after in the scriptural texts (Madhkūr et al. 1985, 202, 204, 217, 221).

Different Qur'anic verses (15:29; 22:05; 32:09; 38:72) were quoted by the advocates of this position as supporting arguments. The following verses were central: "Man We did create from a quintessence of clay. Then We placed him as a fluid-drop (nutfa) in a place of rest, firmly fixed. Then We made the fluid-drop into a clot of congealed blood ('alaqa); then of that clot We made a little lump (mudgha); then we made out of that little lump bones and clothed the bones with flesh; then we developed out of it another creature. So blessed be Allah, the best to create!" (23: 12-14). On the basis of these verses, Dr. Bāsalāma contended that the fertilized ovum passes by three stages: (1) the cellular stage during which the fertilized ovum of a human being can hardly be distinguished from what we can find inside the uteruses of some animals, (2) the 'alaqa and mudgha stage when one can observe a human-like being, and (3) the soul-breathing stage that takes place when the nervous system, including the brain, gets fully shaped and the verse expressed this stage by saying, "Then we developed out of it another creature" (Bāsalāma 1985, 78-79). The religious scholars preferred to consider 'alaqa and mudgha as two distinct stages and thus the total will be four (Ashqar, 'Umar 1985, 138; Sharaf 1985, 185-86). It is clear that the above-mentioned verses gave no indication either about the duration of these stages or about the moment of breathing the soul. These details are given by different Prophetic traditions, especially the tradition of Ibn Mas' $\bar{u} d$ (see the Appendix) in which it is stated that the nutfa stage lasts for 40 days and the same period is also allocated for each of the 'alaqa and the mudgha stages. The tradition added that the angel breathes the soul into the fetus after the lapse of these three stages - that is, after 120 days.

The advocates of this position focused on two main points that can be concluded from the Qur'anic verses and the Prophetic traditions, namely associating the soul-breathing with the beginning of human life and the exact timing of breathing the soul. Concerning the first point, the 
advocates of the first position raised doubts about the plausibility of this association and said that the term "soul" (rüh) is very elastic in the Islamic literature, and different interpretations have been given to this term, so why should breathing the soul in this specific context be interpreted as the beginning of human life (Madhkūr et al. 1985, 208, 255)? However, the advocates of the second position unanimously agreed that breathing the soul, as implied from the Qur'anic verses and as explicitly stated in the tradition of Ibn Mas' $\bar{u} d$, should be taken as the marker of the beginning of human life and not as just an incident that takes place during the life of the embryo. To them, this is how the majority of classical Muslim scholars, including al-Qurțubī (d. 1272), Ibn al-Qayyim (d. 1350), and Ibn Hajar (d. 1449), interpreted this tradition. Further, the religious scholars unanimously agreed that death takes place when the soul leaves the body (Yāsin 1985, 93-95). The Jordanian religious scholar 'Umar al-Ashqar argued further that life as a Qur'anic term means exclusively breathing the soul, and thus the period before this stage can simply be called death and the embryo before breathing the soul, from a Qur'anic perspective, is dead. The Qur'anic verses $(02: 28 ; 40: 11)$ speak about two deaths and two lives that a human being undergoes. After pondering the text of these verses and the interpretations of the Qur'ān commentators, al-Ashqar came to the conclusion that the first death is the embryo before the stage of breathing the soul, the first life is breathing the soul in the embryo, the second death happens when the soul leaves the body, and the second life is the return of the soul to the body in the Hereafter after resurrection. This conclusion also goes in line with the opinion of the Companion Ibn Mas ' $\bar{u} d$ and the authoritative Qur'ān commentator Qatāda (d. 735) (Ashqar, 'Umar 1985, 134-35).

As for the exact timing of breathing the soul, advocates of this position agreed that it cannot be equated with the date of conception but it would take place on a later date. Further, they formulated three different opinions about the exact date of breathing the soul. The neurologist Mukhtār alMahdi tried to reconcile the tradition of Ibn Mas ūd (see the Appendix) with the aforementioned embryonic developments, which show that the development of the brain and the nervous system undergoes a turning point in the twelfth week of pregnancy. To him the three stages mentioned in the tradition of Ibn Mas cu ud should not be taken as three distinct and successive stages, each of which continues for 40 days. He argued that the tradition of Ibn Mas ${ }^{c} \bar{u} d$ was also reported by Muslim but with a little addition, namely, instead of "then he becomes a clot of congealed blood ('alaqa) for a similar period" according to the text reported by al-Bukhārī, the text of Muslim reads, "then he becomes in this a clot of congealed blood ('alaqa) for a similar period." "In this" here means that 'alaqa stage starts during, and not after the end of, the nutfa stage, and the same holds true for the mudgha stage that would also start during, and not after the end of, the 'alaqa stage. 
So, we have here three overlapping and not three distinct forties and thus the total should not be 120 days but less than this. Bearing in mind that the fetus witnesses an important turning point in the twelfth week, then the total of the three overlapping forties should be calculated as 84 days, and this is the date of breathing the soul (Mahdī 1985, 70-71). Al-Mahdì's conclusion did not gain further any support either from the religious scholars who see that it deviates from the traditional viewpoints in Islamic law or from the participating scientists. The second opinion was advocated by the Jordanian religious scholar Muhammad Sulaymān al-Ashqar. He had some critical remarks about the tradition of Ibn Mas ūd (see the Appendix). For instance, the tradition of Ibn Mas ${ }^{c} \bar{u}$ has been reported with different variations, and only one of these variations states that the soul gets breathed after 120 days. The other variations did not make any reference to the soul breathing. Second, only one of these variations mentioned three forties, whereas the other variations mentioned forty nights, forty-two, forty-five, or just an approximate estimation between forty-three and forty-nine. Thus, al-Ashqar argued, breathing the soul should not be estimated later than 40 days except for a few days in order to be on the safe side in such a critical issue upon which a lot of practical rulings in Islamic law are based (Ashqar, Muhammad 1985 126-27). The third opinion, which was supported by the majority, is that the angel breathes the soul into the fetus after 120 days. The main argument for this opinion was the tradition of Ibn Mas' $\mathrm{u} d$ (see the Appendix), which was considered by the advocates of this opinion as the backbone of their argumentation. To them, the tradition should be read without metaphorical interpretation ( $\left.t a^{\prime} w \bar{\imath} l\right)$ because the text is clear enough; three stages each of which continues for 40 days and after the lapse of these three forties, the angel breathes the soul into the fetus (Yāsīn 1985, 91; Ibrāhīm 1985, 75; Bāsalāma 1985, 80-81; Ardughdū 1985, 192; Madhkūr et al. 1985, 202-03). As for the other variations of the tradition of Ibn Mas $\overline{\mathrm{u}} \mathrm{d}$ and the other Prophetic traditions, Shaykh Muhammad Yasīn stated first of all that early authoritative Muslim scholars opined that the tradition of Ibn Mas ${ }^{c} \bar{u} d$, as reported by al-Bukhārī, is the most authentic one and any other contradictory traditions should be metaphorically interpreted in order to fit within its apparent meaning (zähir al-nasss). Second, all authentic traditions and their variations agree that the angel does not visit the embryo before 40 days, and this means that breathing the soul cannot be before the lapse of the 40 days anyhow. So, theoretically speaking there are just two options, namely the angel breathes the soul directly after the lapse of the 40 days or on a later date. The tradition of Ibn Mas ${ }^{c} \bar{u} d$ crossed out the first option, and this is the fact, Yasin argued further, upon which neither the scriptural texts nor the Muslim religious scholars disagreed (Yāsīn 1985, 98-99). As for the tradition of Hudhayfa (see the Appendix) that mentioned that the angel's visit takes place by the fortieth or the forty-fifth night of gestation, 
Dr. Ahmad Shawqī Ibrāhīm said that this tradition made no reference to breathing the soul, which means that the angel is entrusted with doing something else but not breathing the soul (Ibrāhīm 1985, 75; Madhkūr et al. 1985, 249).

In response to the advocates of the first position who stated that their opinion is supported by early authoritative religious scholars such as Abū Hāmid al-Ghazālì (d. 111), the supporters of this position argued that the majority of the early religious scholars support their opinion and not that of the first position. First of all the opinion of al-Ghazāli is contrary to the opinion adopted by the Shāfíī school to which al-Ghazālī himself belongs. Further, the Hanbali school of law also stated that it is allowed to get rid of the embryo before the lapse of 40 days. Different voices in the Hanafi school of law also opined that getting rid of the embryo before breathing the soul is allowed and the soul gets breathed after 120 days. The only approved standpoint within the Mālikì school of law is that the embryo cannot be aborted even before 40 days. However, some Mālikī scholars still opined that it is allowed (Ashqar 1985 127-28).

The advocates of this position also responded to the argument that many of the practical rulings in Islamic law are based on considering the fact that there is pregnancy whether this pregnancy passed the stage of soulbreathing or not yet. Shaykh Muhammad Yasin said although this holds true for many of the practical rulings in Islamic law, some of these rulings did differentiate before and after the soul-breathing stage, such as abortion. For instance, Some Muslim religious scholars opined that it is permitted before breathing the soul, but they all agreed that it is prohibited thereafter. However, a careful examination of all practical rulings that kept pregnancy before the lapse of four months into consideration shows that the rationale of these rulings is not the beginning of human life in its accurate sense as conveyed by the above-mentioned Prophetic traditions but something else. For instance, those who prohibited abortion from the very moment of conception have rationalized this prohibition by saying that the fertilized ovum is the original seed from which the human being will be created later and thus it has a sort of dignity that should be respected. On the basis of the same rationale some religious scholars also prohibited wasting the sperm even before fertilization and prohibited even taking any medicine that would spoil the capacity of being pregnant. As for associating the lapse of the waiting-period of a pregnant woman with the end of her pregnancy, the rationale in this case is to make sure that the uterus of the woman is free from any pregnancy before she can start a marital life with another person. This rationale gets realized when the pregnancy comes to an end whether the soul was breathed into the fetus or not (Yāsīn 1985, 104-05, 108).

As for the slippery slope argument or blocking the means to the evil of abortion as advanced by the first position, advocates of this position 
came up with different counterarguments. The first counterargument is that adopting the opinion that human life starts by breathing the soul does not necessarily legitimize aborting the embryo before ensoulment. Shaykh 'Umar al-Ashqar, who viewed that the embryo prior the soul-breathing stage is to be considered dead from a religious perspective, was eager to clarify this point. He said that it is true that some of the early religious scholars legitimized aborting pregnancy before ensoulment because they believed that it is dead. However, the main question here should not be, does the fetus or the embryo before breathing the soul have human life or not? The main question should be, does God allow any aggression against pregnancy before ensoulment? Reviewing the relevant scriptural texts shows that this aggression is prohibited and the one who does this should be fined according to the precepts of Islamic law. Besides a number of Prophetic traditions, al-Ashqar gave extensive quotations from the fatwas of a number of well-known religious scholars such as al-Ghazālī (d. 1111), Ibn al-Jawzì (d. 1201), and Ibn Taymiyya (d. 1328) in order to support his argument (Ashqar 1985, 147-50). Second, some of the advocates of this position, especially religious scholars, did not agree with the principle that abortion is necessarily an evil that should be warded off and the means to which should be blocked. On the contrary, abortion can sometimes be a source of public benefit. This is the case, for instance, when you give individuals, families, and nations a period during which they can get rid of undesired pregnancies. In this way, many of the dangers that face future generations can be challenged by aborting embryos before the breathing-soul stage. At the end, the borderline between evil and benefit is to be drawn by the law of God and not by the human intellect. So what God makes permissible means that it has benefit and not evil as we might sometimes believe. The Jordanian religious scholar Muhammad al-Ashqar wondered about this and said, "We do not understand why some of our brothers from the physicians' group insist on being rigorous in this issue despite this clarity and the flexibility shown by Muslim religious scholars" (Ashqar 1985, 128; Yāsīn 1985, 105).

\section{Final RECOMMENDATIONS AND FuRTHER DEVELOPMENTS}

One of the main characteristics of the collective Ijtihäd is that the participants should come to a decision in the form of final recommendations upon which there is unanimous agreement or should at least be supported by the majority. After reading the papers and holding three lengthy sessions for discussing the different viewpoints on the beginning of human life, a committee of ten members was selected to draft the final recommendations.

The drafting committee was equally divided between five religious scholars: 'Abd Allāh al-'Īsā (Kuwait), Khālid al-Madhkūr (Kuwait), 'Abd 
al-Sattār Abū Ghudda (Syria), Yūsuf al-Qaradāwīì (born in Egypt and based in Qatar), Muhammad Sulaymān al-Ashqar (Jordan), and five biomedical scientists: 'Abd் al-Raḥmān al-'Awadī (Kuwait), Hassān Hathūut (born in Egypt and based in Kuwait and since 1988 settled in the United States), Ahmad al-Qāḍi (born in Egypt and based in the United States), 'Isāam alShirbīn̄i (born in Egypt and based in Kuwait), and Ahmad Rajāầ al-Jundī (born in Egypt and based in Kuwait). Besides the balance between the biomedical scientists and the religious scholars, there was also a balance, although of a lesser degree, between the advocates of the two main positions discussed above. Hathūt and al-Qādī represented the first position, and al- 'Isāa al-Qaradāwīi, al-Ashqar, and al-Shirbīnī the second position. The remaining members can be considered as neutral ones because they did not express their inclination to any of the two positions during the deliberative process. The text of the final recommendation reads:

The beginning of life occurs with the union of a sperm and an ovum, forming a zygote which carries the full genetic code of the human race in general and of the particular individual, who is different from all other beings throughout the ages. The zygote begins a process of cleavage that yields a growing and developing embryo, which progresses through the stages of gestation towards birth. Second: From the moment a zygote settles (yastaqirr) inside a woman's body, it deserves a unanimously recognized degree of dignity (ihtirām) and a number of religious rulings, known to religious scholars, apply to it. Three: When the embryo reaches the soul-breathing stage, the time of which is subject to controversy, being either forty or 120 days, the fetus acquires greater sanctity (burma), as all scholars agree, and additional religious rulings apply to it. Fourth: Among the most important of these religious rulings are those with pertinence to abortion as pointed out in article seven of the recommendations of the symposium on "Reproduction in Islam." (Madhkūr et al. 1985, 676)

The committee had great difficulties in drafting these recommendations and further difficulties in the final session in order to get them approved. First of all, the recommendations crossed out different points because they were too controversial and the text was confined to the points upon which (semi-)consensus could be reached (Madhkūr et al. 1985, 652). The text, for instance, avoided any reference to the possible differentiation between the beginning of life in the absolute sense and human life in particular, which was very controversial among the participants in this symposium. Further, the text of the recommendations was vague on three crucial points, and each of them was the subject of heated debates among the advocates of the previously mentioned two positions.

The first point was about using the intrauterine device (IUD) and if this would be compatible with the first position that maintains that human life starts by conception. During the deliberations of this symposium Dr. Tal'at al-Qasabī stressed that this point should be clarified in the final recommendations because of its practical relevance to the medical practice (Madhkūr et al. 1985, 319). In the final session held for discussing the final 
recommendations, Shaykh al-Salāmī noticed that the recommendations are silent on this point, although it should be settled because of its significance for the practicing physicians. Shaykh 'Abd al-Bāsit said that the available text of the final recommendations suggests that it is permissible to use the IUD because the fertilized ovum before being settled in the uterus has no dignity. The chairman of the session, Dr. al- 'Awadī, thought it might be necessary to get the available text revised by the drafting committee. Hathūt did not approve the idea because he thinks that the drafting committee cannot add any extra items in the final recommendations because the opinions in the committee will be too divergent (Madhkūr et al. 1985, 651-52). Other physicians such as Najm 'Abd Allāh insisted on appending this point to the final recommendations. He said that we, as physicians, need the standpoint of the religious scholars and they have to tell us: do it or do not do it. Al-Qaradāwī assured Dr. 'Abd Allāh that the physicians can prescribe the IUD as a contraceptive for their patients without feeling any qualms because there is almost a unanimous agreement among the participating religious scholars that the fertilized ovum has no sanctity (burma) as long as it did not get settled in the uterus. The fertilized ovum might have a dignity (ihtirām), but this still does not mean sanctity (Madhkür et al. 1985, 658-59). At the end, the text was not modified, but the participants seemed satisfied with the interpretation given by the religious scholars that permitted using the IUD on the basis of the available text.

The second point was about abortion. It is generally recognized that the viewpoint on abortion is highly influenced by and intertwined with determining the beginning of human life (Beller and Zlatnik 1995, 477-83). Hence, one of the arguments advanced by advocates of the first position in this symposium was to block the means to excessive abortions, and the advocates of the second position also gave their counterarguments on this point. At the very end of the symposium, Dr. Ahmad al-Qādī objected to the text of the fourth recommendation. The first version endorsed the relevant recommendation about abortion of the IOMS symposium held in 1983. What is controversial in this recommendation, al-Qādi argued, is the sentence that refers to the opinion advocated by some of the participants that stated that abortion is permitted as long as it is done before the lapse of 40 days of pregnancy, especially if there is an excuse. Al-Qādī said that this contradicts what was agreed upon here that the zygote enjoys dignity (ihtirām) once it gets settled in the woman's body. "I do not call for revoking what was issued by the symposium on human reproduction, but at least we should not refer to it," al-Qādī explained his request about taking the fourth recommendation out from the final version of the text. Dr. Ahmad Shawqī Ibrāhīm, from the second position, objected to this proposal and said to alQàḍī. "Some of them [the zygotes] have no soul... have no soul. Be 
afraid of God!" The member of the drafting committee, Khālid alMadhkūr, also objected to this proposal and said that al-Qàdī was himself a member of the committee that drafted this text that took us more than four hours. As a compromise, the chairman of the session, Dr. al-'Awadī, suggested reformulating the fourth recommendation, instead of deleting it, in a way that might satisfy both parties (Madhkūr et al. 1985, 668-72). At the end, the fourth recommendation was amended and the final version as quoted above made reference to the 1983 symposium without saying that this symposium adopts the same standpoint.

Al-mīthāq al-Islāmī al-'ālamì li al-akhlāqiyyāt al-țibbiyya wa al-sihhhiyya (The International Islamic Code for Medical and Health Ethics), drafted by the IOMS in 2004, made two references to abortion. The first reference stated that it is prohibited for the physician to abort a pregnant woman unless abortion was necessitated by medical considerations that indicate that woman's health and life are in danger. However, the same text added, abortion is permitted before the lapse of 4 months of pregnancy if it is firmly established that the progress of pregnancy endangers the mother's life with a serious harm and this should be confirmed by a medical committee of at least three specialists (Jundī 2005, 96-97). The second reference quoted the relevant recommendations adopted by the 1983 and 1985 symposia. Thus the controversial sentence adopted by a minority of the participants in the 1983 symposium about the permissibility of abortion before 40 days appeared again (Jundī 2005, 348-49). It is clear that the first reference looks much more restrictive than the second one, and the distinction made in the first reference between abortions done before or after the lapse of 4 months seems purely theoretical. In both cases, there should be a medical necessity with pertinence to the mother's life and the conditions for permitting abortion before 4 months look even much stricter than those required to permit abortion before the lapse of 4 months. This discrepancy between the two references can be explained by understanding the first reference as addressing the issue as far as it concerns the physicians whereas the second reference qouted the IOMS recommendations which are usually meant for common Muslims as well. Another possible explanation is that the two references simply represent the diversity of opinions in contemporary Islamic law on abortion.

\section{EMBRYO RESEARCH}

The third and final point was about using the surplus fertilized ova for scientific research, which proved to be much more controversial than the previous two issues. During the deliberations of this symposium, Dr. Ma'mūn Ibrāhìm commented on the disagreements between the advocates of the aforementioned two positions by saying that he is not much 
interested in their theoretical debates on terminology and typology but eager to find clear answers for two main questions. The first question reads: "Are we allowed to kill the surplus fertilized ova or would we be sinful if we did so?" The second question was about conducting scientific research on these fertilized ova: "Is it permissible, from an Islamic perspective, to use these fertilized ova in scientific research?" (Madhkūr et al. 1985, 289-90). Shaykh 'Umar al-Ashqar, an advocate of the second position, said that the advocates of the first position will surely answer the questions of Dr. Ma'mūn by saying that both practices are categorically forbidden because they believe that human life starts by fertilization. The advocates of the second position, al-Ashqar added, might permit these practices because they believe that human life starts much later, but they also might forbid it, arguing that God did not permit these practices because of other considerations irrelevant to determining the beginning of human (Madhkūr et al. 1985, 300-01). The two religious scholars, 'Abd Allāh al- 'Isā and Yūsuf al-Qaradāwīi, opined that both practices are permissible and they asked the two physicians Hathūt and al-Qādì to give up the idea that human life starts by conception and show instead some flexibility. Human life should at the earliest start when the fertilized ovum gets settled in the uterus and not by conception. Otherwise, al- 'Isāa and al-AlQaradāwī argued, it would be extremely difficult to give space for the two practices proposed by Dr. Ma'mūn (Madhkūr et al. 1985, 315, 318). AlQādī responded positively to this request and finally expressed his support to the contention that human life starts by the settlement of the fertilized ovum in the uterus and not by conception (Madhkūr et al. 1985, 324). However, Dr. Hathūt remained firm in his opinion and argued that the fertilizing ovum can grow even outside the uterus. He referred to the experiments of an Italian scientist where the fertilized ovum could grow up to the seventh week without being settled in the uterus (Madhkūr et al. 1985, 307, 326).

Again the text of the final recommendations was silent on this point. That is why the debates on these two questions continued in the final session held for discussing these recommendations. The Kuwaiti physician al-'Unayzi said that at least the case in the first question should be permitted from an Islamic perspective because it falls within the realm of necessity. In the in vitro fertilization (IVF) processes the physician cannot but fertilize more than one ovum and there is no question about the unavoidability of this situation. Thus, even if we equated killing these fertilized ova with abortion, then it is an unavoidable abortion because the other alternative would be to give these ova to other women, something which is forbidden. So, al- 'Unayzī concluded, we have nothing to do in this case except getting rid of these surplus fertilized ova. Dr. Najm 'Abd Allāh wished that the standpoint of al-'Unayzī would have been one of the final recommendations because of its relevance to the medical 
practice of the physicians. In reference to the second question about using the surplus fertilized ova for scientific experiments, al-'Unayzī stated that Muslim religious scholars have not tackled this issue yet either individually or collectively. However, the issue is very topical at the moment in Europe. "I was amazed when I heard that even the Catholic theologians prohibited this from a religious perspective," al-'Unayzī wondered. If this symposium wants to elaborate on this topic, al- 'Unayzi proposed, we should either give the religious scholars enough time to discuss this or we postpone it to be studied in the future. The chairman of the session, Dr. al- al-'Awadī, and Dr. Hathūt supported the idea of scheduling this issue on the agenda of the IOMS future activities (Madhkūr et al. 1985, 657-58, 660). So, the provisional conclusion of the symposium on this point was that the

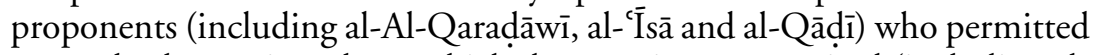
one or both practices about which the questions were raised (including al'Unayzī) outnumbered the opponents who were represented by Dr. Hathūt and Shaykh 'Umar al-Ashqar. However, the participants finally agreed that the issue should be studied more profoundly in one of the future IOMS symposia. This happened when the issue of the surplus fertilized ova was raised in the IOMS symposium Al-ru'ya al-Islāmiyya li ba d d al-mumārasāt al-tibbiyya (the Islamic vision of some medical practices) held in April 1987.

During the IOMS symposium of 1987, Dr. Ma'mūn Ibrāhīm reformulated the questions he raised in 1985 in a six-page paper entitled $\mathrm{Al}$ -

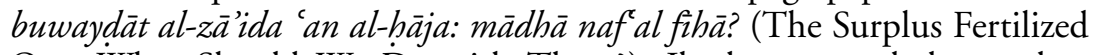
Ova: What Should We Do with Them?). Ibrāhīm argued that a clear distinction should be made between these surplus fertilized ova on one hand and the embryo that has already been implanted in the wall of the uterus on the other hand. The fertilized ovum has just a partial life, which is not different from the life attached to the male sperm and the female nonfertilized ovum, and thus its dignity should be equal to their dignity. Further, conducting this type of research, Ibrāhim concluded, should be seen as a case of necessity. In reference to the IVF technology, Ibrāhīm said, "It is well known that had there been no continuous and arduous scientific research in this field, it would have been impossible to realize this great achievement, nor could we have succeeded in treating the severe cases of infertility" (Ibrāhīm 1995, 450-55). Besides Ibrāhīm, Dr. 'Abd Allāh Bāsalāma also submitted a paper on the same issue. Bāsalāma also participated in the symposium of 1985, and he was an advocate of the second position: human life starts by breathing the soul. In his paper presented in 1985 Bāsalāma opined that the embryo gains sanctity (burma) not by conception but just after 40 days of pregnancy (Bāsalāma 1985, 80). So, the expected conclusion would be that these surplus fertilized ova have no sanctity. However, he did not give answers to the questions raised by Dr. Ibrāhīm in 1985. In his paper submitted to the symposium 
of 1987, Bāsalāma came up with a different conclusion: the embryo has sanctity (burma) and any aggression against this embryo is forbidden, and thus destroying the surplus embryos in the lab can be a punishable offense in Islam. Bāsalāma concluded that the surplus embryos should be implanted in the uterus of the mother again. Neither getting rid of these embryos nor using them for research purposes is permissible (Bāsalāma 1995, 440-49). During the deliberative process, the religious scholars had the opportunity to examine this issue from the perspective of Islamic law. It is clear that the different opinions expressed by the participating religious scholars were resonating with their standpoint about determining the beginning of human life. The Egyptian Hasan al-Shādhilī and the Tunisian Muhạmmad Mukhtār al-Salāmī opined that human life starts by conception and thus having surplus fertilized ova should always be avoided and if they ever existed they should be implanted again in the uterus of the mother. To them, it is not permissible either to kill them or to use them for scientific research purposes. Dr. Hathūt remained holding fast to what he contended in 1985 and thus expressed his support for al-Shādhilī and al-Salāmī. He argued that surplus fertilized ova can in principle be avoided but this will cost extra efforts, time, and money. However, these extras are worth saving life in its first stage, Hathūt concluded. On the other hand, the Egyptian Muhammad al-Ghazālī and the Syrian 'Abd alSattār Abū Ghudda gave their preference to making a distinction between different stages of life. Abū Ghudda specifically objected to what he called "an exaggeration in ascribing sanctity to this fertilized ovum." Dr. Salāh al'Atīqī supported the contention of al-Ghazālī and Abū Ghudda. Al-Ghazālī opined that getting rid of these ova is permissible without commenting on the possibility of using them for scientific research. Abū Ghudda stressed the difficulty to give a simple yes-no answer to these complicated questions. He proposed that these questions should be examined more profoundly by a committee of the religious scholars (Madhkūr et al. 1995, 666-78). Dr. Ma'mūn Ibrāhīm was ultimately dissatisfied because he still did not get clear answers to his questions. To him the text of the final recommendations of the symposium held in 1985, which stated that human life gains dignity only after the settlement of the fertilized ovum in the uterus, should have been seen as guidelines for the religious scholars. Ibrāhimm wondered that there are, however, some religious scholars who reiterate that human life starts by conception. Thus, a new run of discussions ensued where outspoken support for the permissibility of using the surplus fertilized ova for research purposes came up. For instance, the Mufti of Jordan 'Izz alDīn al-Khațīb, Shaykh 'Abd al-Bāșit who expressed a similar opinion but in less clear terms in 1985 and Shaykh Tawfì al-Wầ ${ }^{-} \overline{1}$ stated that these surplus ova have no sanctity ( urma) (Madhkūr et al. 1995, 724-34). Different from the symposium of 1985 , the final recommendations of the 1987 symposium referred explicitly to the surplus fertilized ova. The ideal 
situation, the text stated, is to have no surplus fertilized ova. If this was unavoidable and there were surplus fertilized ova, then the majority of the religious scholars stated that they have neither sanctity ( ( urma) of any type nor dignity (ihtiramm) before being implanted in the wall of the uterus. Thus, the text continued, it is not prohibited to destroy these ova by any means. The text also referred to the position of the minority among the participants, which argued that these ova represent the first stage of the human being whom God has dignified. About what to do with these surplus ova, the text gave three options: namely, destroying them, using them for scientific research purposes, or letting them die in a natural way. Finally, the text gave preference to the third option by saying that it seems that it is the least option that would violate sanctity (akhaffuha hurma) because it does not involve direct aggression against life (Madhkūr et al. 1995, 757). These recommendations represent an important breakthrough in this issue compared to the symposium held in 1985. It is now on the IOMS agenda as one of the main issues that deserve a profound examination and thus a distinct reference has now been made to this issue in the final recommendations. Using these surplus ova for scientific research purposes was mentioned as one of the possible options although preference was ultimately given to another option, namely letting them die in a natural way. At any rate, the recommendations of the symposium held in 1987 still did not say the final word and further meetings led to further developments on this issue.

In October 1989, the IOMS organized a symposium where a special section was dedicated to the aborted embryos as a possible source for human organs. In this section, Dr. Ma'mūn Ibrāhīm submitted a revised version of his paper already read in 1987. The conclusion of the new version was much bolder. Ibrāhīm stated that such research must be encouraged and promoted because of its medical benefits (Ibrāhīm 1994, 193-200). Dr. 'Abd Allāh Bāsalāmā also submitted a revised version of his paper read in 1987 and also stuck to his contention that this type of research should be prohibited from an Islamic perspective (Bāsalāmā 1994, 183-92). Dr. Hathūt, one of the strong opponents to using the surplus fertilized ova in scientific research, submitted a paper in which he reformulated the opinion he already expressed in 1985 and 1987 (Hathūt 1994, 163-75). The most important development in the symposium of 1989 was the contribution of the three Jordanian religious scholars who submitted three papers on this issue. In his extensive paper, Muhammad $\mathrm{Na}^{\mathrm{c}} \mathrm{i} m$ Yasīn concluded that using these surplus ova for scientific research purposes is in principle allowed in Islam (Yasīn 1994, 332-33). 'Abd al-Salām al'Abbādī disagreed with Yasīn's conclusion and opined that this type of research should be forbidden ('Abbādī 1994, 389). 'Umar Sulaymān alAshqar was satisfied with quoting the final recommendations adopted by the IOMS symposium held in 1987 and commented upon by saying that 
the majority of the participants in this symposium permitted conducting research on the surplus ova before and also after fertilization. Further, alAshqar aptly remarked that restudying this issue will not unify the diverse opinions because it is hardly possible to reach a unified opinion on such complicated issues (Ashqar 1994, 395-96). The final recommendations of this symposium adopted those of 1987 and quoted them literally but added an important item "According to the opinion advocated by the majority (which was not approved by some others) which permitted destroying the fertilized ova by whatever means before their implantation in the uterus, there is no barrier to conduct legitimate scientific experiments without multiplying them. However, some objected totally to this" (Jundī 1994, 648).

The same issue was discussed for the fourth time in a meeting organized in March 1990 by the International Islamic Fiqh Academy (IIFA) affiliated with the Organization of the Islamic Conference. The two papers of Ibrāhīm and Bāsalāma of 1989 were presented again, but neither Ibrāhīm nor Bāsalāma attended the meeting. In contrast to the previous symposia where the participants were exclusively from a Sunnī background, the Iranian Shīì religious scholar, Muhammad 'Alī al-Taskhīrī participated in the IIFA meeting and expressed his support for the recommendations adopted by the IOMS in 1987 (Majallat 1990, 2116). The resolution adopted by the IIFA stated that if a surplus of fertilized ova became unavoidable, then the only possible option is to let them die in a natural way. Thus, destroying the ova and using them for scientific research were both eliminated from the permissible options. The discrepancy between the conclusion of the IOMS symposium held in October 1989 and that of the IIFA meeting held in March 1990 was traced back to the influential role of specific figures in the IIFA meeting who opposed the scientific use of these surplus ova and simultaneously the absence of other important figures who managed to defended the permissibility of this scientific use in the IOMS symposium (Eich 2008, 69-72). We also add here another possible reason, namely the centrality of $s a d d$ al-dhara ${ }^{\prime c}{ }^{\circ}$ (literally blocking the means to evil and generally understood as the slippery slope argument) in the deliberative process during the IIFA meeting. Almost all opponents to the scientific use of the surplus fertilized ova spoke about blocking the means to evil as a main argument. This was true to the extent that the other voices expressed their worries about an exaggerative use of sadd al-dharä $i^{\prime} i$. For instance, the Tunisian religious scholar al-Tayyib Salāma argued that following this way of argumentation would eventually lead to adopting the approach of the strict Christian interpretations. In reference to the other principle in Islamic law, namely al-masälih al-mursala (public benefits), the Kuwaiti religious scholar Muhammad 'Abd al-Ghaffār al-Sharīf also argued that this excessive use of sadd al-dhara $\bar{a} i$ ' would harm the benefits of the physicians (Majallat 1990, 2117-29). 
It is noteworthy that the resolution adopted by the IIFA in March 1990 was not perceived by the IOMS as a revocation of their own standpoints endorsed in earlier symposia, but rather as parallel opinions each of which has its own place and possible application within Islamic law. For instance, the published proceedings of the IOMS symposium held in 1989 that issued a permissive recommendation about using the surplus fertilized ova for scientific research was appended by the resolutions adopted by the IIFA meeting held in March 1990 (Jundī 1994, 656-57). The same tradition was also followed when the IOMS drafted the international Islamic code for medical and health ethics by the end of 2004. The code referred to the recommendations adopted by the IOMS in 1987 and 1989 besides the resolution of the IIFA adopted in 1990 without giving preference to any of these recommendations (Jundī 2005, 387-90). These developments show that practicing Ijtihād on a collective level does not necessarily mean the absence of the diversity of opinions in contemporary Islamic law.

The debate around the use of the surplus fertilized ova for scientific research purposes witnessed a turning point when it was raised within the context of stem cell research. Daniel Callahan has rightly said, "The aim we have in mind in placing the question [when does human life begin?] in the first place will have a bearing on the answer we consider appropriate" (Callahan 1988,29). Callahan's statement is best applicable to this case. The proposed scientific benefits of conducting stem cell research were crucial in shifting the debate from sadd al-dhara ${ }^{\prime}{ }^{c}$ (blocking the means to evil) discourse that was dominant in the IIFA meeting held in 1990 to al-masaslih al-mursala (public benefits) approach in the subsequent discussions. It seems that the religious scholars became convinced that the benefits of stem cell research outweigh the possible harms or means to evil that should be blocked. The Islamic Fiqh Academy (IFA) affiliated with the Muslim World League (MWL) issued a resolution on stem cell research in its seventeenth session held in December 2003. The resolution reads, "It is permissible to obtain, develop, and utilize the stem cells for medical treatment or lawful scientific research if the source is also lawful." The resolution gave five examples of these lawful sources, and one of them was the surplus fertilized ova in the IVF processes (Majallat 2004, 293-95). The same standpoint was adopted by the IOMS during their international symposium held in November 2007 under the title "Dilemma of Stem Cells: Research, Future and Ethical Challenges." The second item of the recommendations reads, "Fertilized eggs surplus to the requirements of IVF possess no privileged status and enjoy no sanctity before their implantation. It follows that there is no objection to any method of disposing of them. Hence, using them for the purposes of treatment and scientific research is better than wasting them" (http://www.islamset.com/ioms/cairo2007/index.html). We see here an important development because using the surplus fertilized ova for scientific research is not seen just as one of the options as was the case 
in the IOMS symposia held in 1985 and in 1987. Now it is deemed as the better option. To my mind, this shift in the debate has to do with the new context in which this debate was rekindled by the beginning of the twenty-first century, namely, the stem cell research.

Now a final word about the current relevance of the IOMS symposium on human life held in 1985. The aforementioned developments are just examples to show how seminal this symposium has been in the field of Islamic bioethics. In 2000, the IOMS published a summary of this symposium and in his foreword to this publication, the IOMS president Dr. al-'Awadī stressed the up-to-date relevance of this symposium by saying, "Though 15 years have passed since this symposium was held, it is still representing a clear concept of the academic methodology adopted by the IOMS for studying such topics" (Jundī 2000, 7). Also the topic "the beginning of human life," which was handled in the international Islamic code for medical and health ethics issued by the IOMS in December 2004, was solely based on the recommendations of this symposium (Jundī 2005, 352-54).

\section{THE INTERPLAY OF ISLAM AND THE WEST}

The above-mentioned discussions have all to do with Islam and specifically Islamic bioethics. However, the West and specifically the biomedical achievements and the bioethical debates taking place in this part of the world cannot be detached from these Islamic bioethical discussions. This article argues that the interplay of Islam and the West was an important dimension during the proceedings of the IOMS symposium held in 1985 and also the subsequent relevant events.

First of all, one of the main incentives of holding this symposium, as outlined by the IOMS president Dr. al-'Awadīi, was to discuss the recent scientific advancements achieved in Western countries from an Islamic perspective. Further, al-'Awadī added, the symposium also aims to examine the bioethical debates run by non-Islamic organizations (Madhkūr et al. 1985, 18-19). Hence, holding this symposium to discuss the beginning of human life should be understood within the context of contemporary parallel debates among Western biomedical scientists and ethicists. The Egyptian zoologist 'Abd al-Ḥāfiz Hilmī made reference to such debates in the United States, especially in 1981 and 1982. He argued, in agreement with other participants in the symposium, that it would be enriching to examine these debates not necessarily to follow suit but for the sake of consultation (Madhkūr et al. 1985, 260-61).

Further, the proceedings of the IOMS symposium held in 1985 and the subsequent debates show that biomedical and bioethical arguments developed in the West were integrated in the religious argumentation between the religious scholars and the physicians who participated in the 
symposia held in the Muslim world. For instance, the advocates of the first position who opined that human life starts from the moment of conception made use of the slippery slope argument or sadd al-dhara ${ }^{\prime} i^{c}$ as known in Islamic law. They argued that those who say that human life starts at later stages open the doors to evil, namely abortion. In order to prove the validity of this argument, Shaykh al-Salāmī appended his paper with a full Arabic translation of an article published by the French newspaper Le Mond and Dr. al-Qādi referred to the abortion statistics available in the United States (Madhkūr et al. 1985, 121-22, 298). Shaykh Muhammad al-Ashqar who adopted a permissive standpoint toward abortion in the early stages of pregnancy had to defend his standpoint against those who criticized his approach of Westernization (Madhkūr et al. 1985, 128). Also when Shaykh 'Umar al-Ashqar argued that the life of the embryo before breathing the soul is not a human life but rather something compared to botanical life, he supported his argument by quoting a Western source. Al-Ashqar gave a long quotation from the Arabic edition of The Evidence of God in an Expanding Universe edited by John Clover Monsma (Ashqar 1985, 136-37). The third example to be given here is Dr. Mukhtār al-Mahdī, who argued that human life starts in the twelfth week. To defend this contention, alMahdi dedicated more than $95 \%$ of his paper to explaining the embryonic developments, especially those with relevance to the nervous system and specifically the brain. This information was based on 21 scientific studies, the majority of which were published in the American Journal of Obstetrics and Gynecology. However, al-Mahdī tried to support his contention with a specific metaphorical interpretation of the tradition of Ibn Mas ${ }^{c} \bar{u} d$ (see the Appendix) in order to come to the conclusion of 12 weeks (Mahdi 1985, 62-73). During the deliberations, al-Mahdī raised the question if his interpretation might fit within the Islamic tradition. In response, alQaraḍ̄īī said that no Muslim religious scholar has ever adopted such a metaphorical interpretation (Madhkūr et al. 1985, 312). Strikingly enough, almost all Western countries use the twelfth week of pregnancy as the limit for legal abortion (Beller and Zlatnik 1995, 478). So, it seems that alMahdī here was trying to integrate a Western standpoint into the Islamic tradition.

Similar modes of the interplay of Islam and the West can also be traced in the subsequent discussions relevant to the beginning of human life. For instance, the IOMS symposium held in October 1989 examined the issue of embryo research. Dr. Hathūt was a stern opponent to conducting this type of research and warned that most of the embryos used for research are aborted ones. In reference to the slippery slope (sad al-dhara $\bar{i}^{\circ}$ ) argument, Hathūt said that means to this evil should be blocked and embryo research should be declared as prohibited from an Islamic perspective. In order to elaborate on the possible evils of such a research, he referred to an embryo research scandal of an American research institute. According to 
Hathūt, this institute had a deal with an agent in a Southeast Asian country who provided them with the embryos they need for research. Further, experiments were conducted on living embryos during pregnancy because the mothers already planned to have an abortion for one reason or another. After abortion, the aborted embryos underwent surgical operations without using anesthetics. The case went so far to the extent that a cosmetic company used the living aborted embryos in order to examine the effect of the chemical substances on the human complexion (Jundī 1994, 172-73). ${ }^{2}$ In the same symposium, Hathūt referred to Germany, which banned all use of human embryos in biomedical research. As for the surplus of fertilized ova in the IVF processes, the law even banned initiating such a surplus. This unique decision, Hathūt explained, had to do with Germany's meticulous sensitivity toward the dignity and sanctity of the human being because of the infamous medical experiments conducted on the prisoners of war and the detainees during the Nazi regime. Hathūt concluded that this law goes in line with Islamic ethics (Hathūt 1994, 175). The publication of this symposium was appended by the English text of the article "Germany to Ban Embryo Research,” published by Science in August 1989 (Kirk 1989, 464; Jundī 1994, 665). This German law had clear influence on the final recommendations that stated that creating a surplus of fertilized ova during IVF treatments should be avoided, and this is now technically available and some European countries (West Germany) already do accordingly (Jundī $1994,665)$. The influence of this law became more visible during the IIFA meeting held in March 1990, which categorically forbade the creation of surplus fertilized ova (Majallat 1990, 2155).

The interplay of Islam and the West in these gatherings held in the Muslim world is not restricted to importing biomedical and bioethical information from the West. Another dimension of this interplay is the interest of these organizations such as the IOMS in conveying their message to Muslims living in the West as religious minorities. The editorial of the published volume on the symposium held in 1985 said about the importance of studying the beginning and the end of life, "Examining these two issues became an urgent necessity not only for the Muslim countries but also for the Muslim minorities which have expanded and grown. They are (1) eager to get clear answers about what is lawful and what is prohibited in this respect and (2) some of them work in this field and are keen to know the limits of their work" (Madhkūr et al. 1985, 9-10). Translating the whole voluminous work of this symposium into English might be seen as a step in this regard so that the IOMS work can be accessible for a wider audience among these minorities. ${ }^{3}$ The voice of the IOMS also finds its way to Muslims living in the West via Islamic organizations established and functioning in the West. Just as an example we refer to the Islamic Medical Association of North America (IMANA). It is noteworthy that some of the prominent figures who regularly participated in the IOMS activities 
were also active in the IMANA such as Hassān Hathūt and Ahmad alQādīi. Specifically about the beginning of human life, which was discussed by the IOMS in its symposium held in 1985, an English translation of the paper presented by the Jordanian religious scholar Muhammad $\mathrm{Na}^{\mathrm{i}} \mathrm{i} \mathrm{m}$ Yasin was published in 1990 by the IMANA's journal, The Journal of Islamic Medical Association of North America (Yaseen 1990, 159-67). In 2005 When the IMANA formulated their position about the definition of life, their position was echoing the recommendations of the IOMS symposium, and they also made reference to the aforementioned paper of Muhammad $\mathrm{Na}^{c} \mathrm{i} m$ Yasin (Athar and Hossam 2005, 36, 41). Further, in personal communication with Dr. 'Abd al-Rahmān al-'Awaḍi and Dr. Ahmad al-Jundī, respectively, the president and the adjunct secretary of the IOMS, I knew that they have different plans in order to intensify their direct contacts with Muslims living in the West in the near future. ${ }^{4}$

\section{CONCLUSIONS}

The proceedings of the IOMS symposium held in 1985 represent one of the early chapters in contemporary Islamic bioethics where both religious scholars and biomedical scientists started to discuss bioethical issues collectively. The proceedings of this symposium and its final recommendations proved to be seminal on two levels: shaping the Islamic standpoints on different bioethical issues and delineating the main characteristics of contemporary independent legal reasoning on a collective basis ( Ijtihād jamā $\bar{\imath})$.

As for its relevance to contemporary Islamic bioethics, the symposium showed that there was a great variety of opinions in the Islamic tradition about the exact beginning of human life. These opinions were examined and, when necessary, filtered at the hand of modern scientific knowledge. By the end of the symposium, two main positions remained. The first position saw that human life begins by conception and at the hand of different debates the majority of the advocates of this position moved this to a later moment, namely when the fertilized ovum gets settled in the wall of the uterus. The second position opined that human life starts much later, namely, when the soul gets breathed into the fetus and this takes place at earliest after 40 days of pregnancy and at latest by the lapse of 4 months. The second position gained the support of the majority of the participants, and this was also reflected in the final recommendations that stated that life has three grades: it starts by conception, then gains dignity (ihtirām) by implantation, and finally acquires sanctity ( hurma) just after breathing the soul.

The subsequent discussions among Muslim religious scholars and physicians on different bioethical issues were always echoing the vision of one of these two positions. Those who had restrictive standpoints toward 
abortion resonated with the vision of the first position, and the others who adopted a permissive standpoint represented the second position. The opponents to embryo research were influenced by the first position, and those who advocated this type of research quoted the arguments of the second position. The same holds true to the standpoints on many other issues, including the use of an intrauterine device (IUD) and recently the stem cell research, where the standpoint of the second position clearly had the upper hand and thus got legitimized from an Islamic perspective. Also in September 2004, when the Regional Office for the East Mediterranean, World Health Organization (WHO) elaborated a position on human cloning, the recommendations of the IOMS symposium were one of the guidelines in this report when it discussed the issue of embryonic stem cell research (Regional Committee 2004, 4).

This symposium also showed important developments in the field of contemporary independent legal reasoning (Ijtih $\bar{a} d)$. First of all, both religious scholars and scientists agreed on the necessity of practicing Ijtihād collectively rather than individually in order to be able to tackle such complicated bioethical issues. Second, the proceedings of this symposium showed that the conclusions reached at the end of the Ijtihäd process are not solely based on how to approach the scriptural texts or the opinions of classical religious scholars. Modern scientific knowledge proved to be one of the essential tools in this process and some classical interpretations and contentions were crossed out because of their incompatibility with modern science. We also have seen that Western bioethical and legal standpoints started to get integrated into the Ijtihād process. The aforementioned German law on embryo research and the Western laws on abortion serve as illuminating examples. Third, the participants in these discussions are aware of the fact that their conclusions are based on human endeavor, namely Ijtihad, and thus they do not represent a court of final appeal. This gives space for diversity of opinions and also for further examination and revision of these conclusions whenever relevant new biomedical or bioethical developments take place.

\section{Notes}

1. In English literature, it is also sometimes called Academy of Islamic Research or Islamic Research Council.

2. I did my best to trace this embryo scandal in English sources but in vain. So, I do not know to what extent the presentation of Hathūt to this incident is influenced by his anti-embryo research standpoint.

3. The English version appeared in 1989 under the title Human Life: Its Inception and End as Viewed by Islam. This article is based on the Arabic version because it is the original one. Additionally, I noticed that the English version does not help elaborating on different technical terms, which were essential in the discussions.

4. This was during the Honour Class For God's Sake? Bio-medicine, Law and Religion organized by Leiden University during the period May 25 to June 24, 2010, where Dr. al-Jundī was one of the invited lecturers. 


\section{APPENDIX}

- The Prophetic tradition reported by al-Bukhārī and Muslim on the authority of Ibn Mas ${ }^{c} \bar{u} d$, referred to in the main text as the tradition of Ibn Mas ${ }^{c} \bar{u} d$.

\section{ARABIC TEXT}

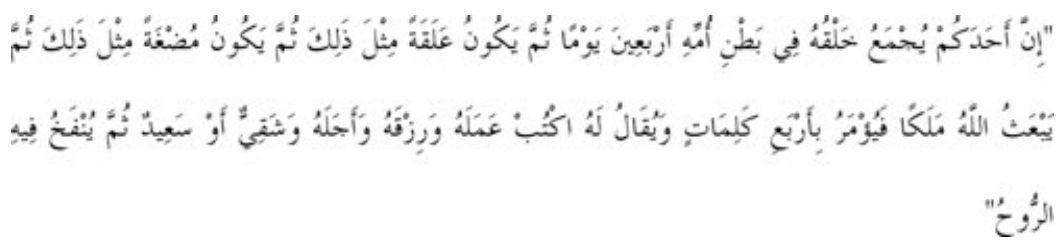

\section{ENGLISH TRANSLATION}

"The creation of one of you is put together in his mother's womb in 40 days, then he becomes a clot of congealed blood ('alaqa) for a similar period, then a little lump (mudgha) for a similar period. Then Allah sends an angel who is ordered to write four things. He is ordered to write down his (i.e., the new creature's) deeds, his livelihood, his (date of) death, and whether he will be blessed or wretched. Then the soul is breathed into him."

- The Prophetic tradition reported by Muslim on the authority of Hudhayfa Ibn Usayd, referred to in the main text as the tradition of Hudhayfa

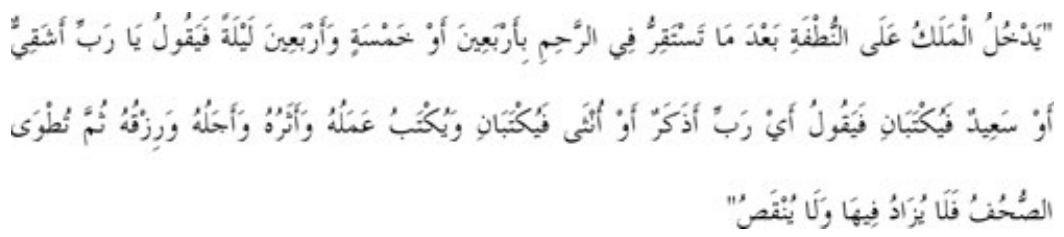

\section{ENGLISH TRANSLATION}

When the fluid-drop (nutfa) remains in the womb for 40 or 45 nights, the angel comes and says: My Lord, will he be blessed or wretched? And both these things would be written. Then the angel says: My Lord, would he be male or female? And both these things would be written. And his deeds and actions, his death, his livelihood; these are also recorded. Then his document of destiny is rolled and there is neither addition to nor subtraction from it.

\section{REFERENCES}

'Abbādī, 'Abd al-Salām al-. 1994. Hukm al-istifāda min al-ajinna al-mujhada aw al-zā'ida 'an al-hāja [The ruling on benefiting from the aborted or the surplus embryos]. In Ru'ya 
Islāmiyya li zirāa at ba'd al-a déa al-bashariyya [An Islamic vision of transplanting some human organs], ed. Aḥmad Rajāī al-Jundīi, 375-92. Kuwait: Islamic Organization for Medical Sciences.

'Abd Allāh, 'Abd Allāh Muhammad. 1985. Al-hayāh bidāyatuhā [Life: its beginning]. In Al-hayah al-insāniyya: bidāyatuhā wa nihāyatuhä fi al-mafhūm al-Islāmì [Human life: its beginning and its end from an Islamic perspective], eds. Khālid al-Madhkūr, 'Alī Sayf, Ahmad Rajā'ì al-Jundī, and 'Abd al-Sattār Abū Ghudda, 154-69. Kuwait: Islamic Organization for Medical Sciences.

Aksoy, Sahin. 2007. The Beginning of Human Life and Embryos: A Philosophical and Theological Perspective. Reproductive BioMedicine Online 14(Suppl. I): 86-91

'Ammārī, 'Abd al-Qādir bin Muhammad al-. 1985. Bidāyat al-hayāh [The beginning of life].

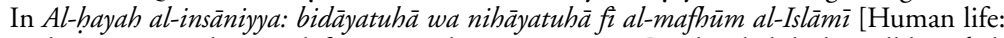
its beginning and its end from an Islamic perspective], ed. Khālid al-Madhkūr, 'Alī Sayf, Ạmmad Rajā̄ì al-Jundī, and 'Abd al-Sattār Abū Ghudda, 170-181. Kuwait: Islamic Organization for Medical Sciences.

Ardughdū, Muștafā Șabrī. 1985. Bidāyat al-hayāāh al-insāniyya [The beginning of human life]. In Al-hayāh all-insāniyya: bidāyatuhā wa nihāyatuhā fì al-mafhūm al-Islämī [Human life: its beginning and its end from an Islamic perspective], ed. Khālid al-Madhkūr, 'Alī Sayf, Ạmad Rajāài al-Jundīi, and 'Abd al-Sattār Abū Ghudda, 189-94. Kuwait: Islamic Organization for Medical Sciences.

Ashqar, Muhammad Sulaymān al-. 1985. Bidāyat al-hayāh [The beginning of life]. In Al-hayāh al-insāniyya: bidāyatuhà wa nihāyatuhā fì al-máfhūm al-Islāmì [Human life: its beginning and its end from an Islamic perspective], eds. Khālid al-Madhkūr, 'Alī Sayf, Ahmad Rajā’’ì al-Jundī, and 'Abd al-Sattār Abū Ghudda, 123-29. Kuwait: Islamic Organization for Medical Sciences.

Ashqar, 'Umar Sulaymān al-. 1985. Bad' al-ḥayāh wa nihāyatuhā [The beginning of life and its end]. In Al-ḩayāh al-insāniyya: bidāyatuhā wa nihäyatuhā fì al-mafhūm al-Islāmī [Human life: its beginning and its end from an Islamic perspective], eds. Khālid al-Madhkūr, 'Alī Sayf, Ahmad Rajā̄̄i al-Jund̄̄, and 'Abd al-Sattār Abū Ghudda, 130-53. Kuwait: Islamic Organization for Medical Sciences.

. 1994. al-istifāda min al-ajinna al-mujhaḍa aw al-zā’ida 'an al-hāja fì zirācat ala'ḍā' wa al-tajārib al-'ilmiyya [Benefiting from the aborted or the surplus embryos for organ transplantation and scientific experiments]. In Ru'ya Islāmiyya li ziră $\bar{c}^{c} a t$ $b a^{c} d$ al-a $d \vec{a}$ ' al-bashariyya [An Islamic vision of transplanting some human organs], ed. Ahmad Rajā̄î̀ al-Jundī, 393-99. Kuwait: Islamic Organization for Medical Sciences.

Athar, Shahid and Hossam E. Fadel. 2005. Islamic Medical Ethics: The IMANA Perspective. Journal of Islamic Medical Association of North America 37: 33-42.

Atighetchi, Dariusch. 2007. Islamic Bioethics: Problems and Perspectives. Springer: Dordrecht, the Netherlands.

Bāsalāma, 'Abd Allāh. 1985. Al-ḥayāh al-insāniyya dākhil al-rahim: bidāyatuhā wa nihāyatuhā [Human life inside the womb: its beginning and its end]. In Al-hayāh al-insāniyya:

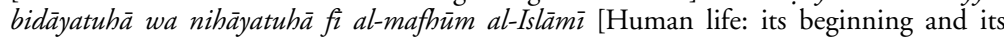
end from an Islamic perspective], eds. Khālid al-Madhkūr, 'Alī Sayf, Ahmad Rajā̄i alJundī, and 'Abd al-Sattār Abū Ghudda, 77-83. Kuwait: Islamic Organization for Medical Sciences.

. 1994. Al-istifāda min al-ajinna al-mujhada aw al-fā'iḍa fì zirāâat al-a đḍā' [Making use of the aborted and the surplus embryos for transplanting organs]. In Ru'ya Islämiyya li zirā $\bar{c}^{c} a t$ $b a^{c} d$ al-a'd $\vec{a}^{\prime}$ al-bashariyya [An Islamic vision of transplanting some human organs], ed. Ahmad Rajāī al-Jundīi, 183-92. Kuwait: Islamic Organization for Medical Sciences. - 1995. Masìr al-ajinna fì al-bunūk [The fate of the embryos (preserved) in the banks]. In Al-ru'ya al-íslāmiyya li ba'd al-mumārasāt al-tibbiyya [The Islamic vision of some medical practices], eds. Khālid al-Madhkūr, 'Alī Sayf, Ahmad Rajāài al-Jundīi, and 'Abd al-Sattār Abū Ghudda, 440-49. Kuwait: Islamic Organization for Medical Sciences.

Bāṣiț, Badr al-Mutawallī 'Abd al-. 1985. Bidāyat al-ḥayāh al-insāniyya [The beginning of human life]. In Al-hayāh al-insāniyya: bidāyatuhā wà nihāyatuhā fì al-mafhüm al-Islāmì [Human life: its beginning and its end from an Islamic perspective], eds. Khālid al-Madhkūr, 'Alī Sayf, Aḥmad Rajā̄i al-Jundī, and 'Abd al-Sattār Abū Ghudda, 109-10. Kuwait: Islamic Organization for Medical Sciences. 
Beller, Fritz K. and Gall P. Zlatnik. 1995. The Beginning of Human Life. Journal of Assisted Reproduction and Genetics 12(8): 477-83.

Callahan, Daniel. 1988. The Beginning of Human Life: Philosophical Considerations. In What Is a Person? ed. Michael F. Goodman, 29-55. Clifton: The Human Press Inc.

Eich, Thomas. 2008. Decision-Making Process among Contemporary 'Ulama': Islamic Embryology and the Discussion of Frozen Embryos. In Muslim Medical Ethics: From Theory to Practice, eds. Jonathan E. Brockopp and Thomas Eich, 61-75. Columbia, South California: Univ of South California Press.

Ghaly, Mohammed. 2010. Human Cloning Through the Eyes of Muslim Scholars: The New Phenomenon of the Islamic International Religio-scientific Institutions. Zygon: Journal of Religion and Science 45(1): 7-35.

Hathūt, Hassān. 1994. Istikhdām al-ajinna fì al-bahth wa al-'ilāj [Using the embryos for research and medical treatment]. In Ru'ya Islämiyya li zirā $\bar{c}^{c} a t b a^{c} d a l-a^{c} d \bar{a}^{\prime}$ al-bashariyya [An Islamic vision of transplanting some human organs], ed. Ahmad Rajāīi al-Jundī, 163-75. Kuwait: Islamic Organization for Medical Sciences.

. 1985. Bidāyat al-hayāh [The Beginning of Life]. In Al-hayāh al-insāniyya: bidāyatuhā wa nihāyatuhā fi al-mafhīm al-Islämì [Human life: its beginning and its end from an Islamic perspective], ed. Khālid al-Madhkūr, 'Alī Sayf, Ahmad Rajā'ì al-Jundī, and 'Abd al-Sattār Abū Ghudda, 55-61. Kuwait: Islamic Organization for Medical Sciences.

Ibrāhīm, Ahmad Shawqī. 1985. Matā bada' at hayāt al-insān [when did the life of the human being start]. In Al-hayā̄h al-insāniyya: bidāyatuhā wa nihäyatuhā fì al-mafhüm al-Islāmì [Human life: its beginning and its end from an Islamic perspective], ed. Khālid al-Madhkūr, 'Alī Sayf, Aḥmad Rajā̄ì al-Jundīi, and 'Abd al-Sattār Abū Ghudda, 74-76. Kuwait: Islamic Organization for Medical Sciences.

Ibrāhīm, Ma'mūn al-Hāj 'Alī. 1995. Al-buwaydāt al-zāida 'an al-hāja: mādhā naf al fihāe [The surplus fertilized ova: what should we do with them?]. In Al-ru'ya al-Islāmiyya li ba'd al-mumārasāt al-tibbiyya (The Islamic vision of some medical practices), eds. Khālid aiMadhkūr, 'Alī Sayf, Ahmad Rajā̄î̀ al-Jundī, and 'Abd al-Sattār Abū Ghudda, 450-55. Kuwait: Islamic Organization for Medical Sciences.

. 1994. Al-istifāda min al-ajinna al-mujhaḍa aw al-zā'ida 'an al-hāja fì al-tajārib al'ilmiyya wa zirā'at al-a 'dā' [Making use of the aborted and the surplus embryos for scientific experiments and transplanting organs]. In Ru'ya Islämiyya li zira $\bar{a}^{c} a t b a^{c} d$ al-a'd $d \bar{a}^{\prime}$ al-bashariyya [An Islamic vision of transplanting some human organs], ed. Aḥmad Rajā̄̄̄ al-Jundī, 193-200. Kuwait: Islamic Organization for Medical Sciences.

Jundī, Ahmad Rajā̄ì al-. 1994. Ru'ya Islāmiyya li zirā' at ba'd al_a'dä' al-bashariyya [An Islamic vision of transplanting some human organs]. Kuwait: Islamic Organization for Medical Sciences.

. 2000. Summary of the Seminar on Human life: Its Inception and End as viewed by Islam. Kuwait: Islamic Organization for Medical Sciences.

2005. Al-mìthāq al-Islāmī al-ālamì lì al-akhlāqiyyāt al-tibbiyya wa al-sihhhiyya [The international Islamic code for medical and health ethics]. Kuwait: Islamic Organization for Medical Sciences.

Kamali, Mohammad Hashim. 2003. Principles of Islamic Jurisprudence. Cambridge: The Islamic Texts Society.

Kirk, Don. 1989. Germany to Ban Embryo Use. Science 245(4917): 464.

Kurjak, Asim J., Carrera, Jose Maria, Laurence B. McCullough, and Frank A. Chervenak. 2007. Scientific and Religious Controversies about the Beginning of Human Life: The Relevance of the Ethical Concept of the Fetus as a Patient. Journal of Perinatal Medicine 35: $376-$ 83.

Madhkūr, Khālid al-, Sayf, 'Alī̄, Jundī, Ahmad Rajā’ī al-, and Abū Ghudda, 'Abd al-Sattār, eds. 1985. Al-hayāh al-insāniyya: bidāyatuhā wa nihāyatuhā fì al-mafhūm al-Islāmì [Human life: its beginning and its end from an Islamic perspective]. Kuwait: Islamic Organization for Medical Sciences.

1995. Al-ru'ya al-Islämiyya li ba'd al-mumārasāt al-tibbiyya [The Islamic vision of some medical practices]. Kuwait: Islamic Organization for Medical Sciences, 2nd edition.

Mahdī, Mukhtār al-. 1985. Bidāyat al-hayāh al-insāniyya [The beginning of human life]. In

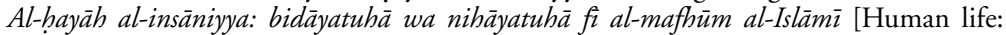
its beginning and its end from an Islamic perspective], eds. Khālid al-Madhkūr, 'Alī 
Sayf, Aḥmad Rajāàì al-Jundīi, and 'Abd al-Sattār Abū Ghudda, 62-73. Kuwait: Islamic Organization for Medical Sciences.

Majallat al-Majma a al-Fiqhī al-Islāmī. 2004. Mecca: Muslim World League, 15(17): 293-95.

Majallat Majma' al-Fiqh al-Islāmī. 1990. Jeddah: International Islamic Fiqh Academy 6(3): 2080-131.

Qaraḍāwī, Yūsuf al-. 1994. Al-Ijtihād al-mu'āsir bayna al-indibāt wa al-infirāt [Contemporary independent legal reasoning between discipline and disorder]. Cairo: Dār al-Tawzī wa al-Nashr al-Islämiyya.

Regional Committee for the Eastern Mediterranean. 2004. Development of a Regional Position on Human Cloning. Cairo: Regional Office for the East Mediterranean, World Health Organization.

Sachedina, Abdulaziz. 2009. Islamic Biomedical Ethics: Principles and Application. Oxford: Oxford University Press.

Salāmī, Muhammad Mukhtār al-. 1985. Al-hayāh al-insāniyya: bidāyatuhā [Human life: its beginning]. In Al-hayāh al-insāniyya: bidāyatuhā wa nihāyatuhā fi al-mafhūm al-Islämī [Human life: its beginning and its end from an Islamic perspective], eds. Khālid alMadhkūr, 'Alī Sayf, Ahmad Rajā’ī al-Jundīe and 'Abd al-Sattār Abū Ghudda, 111-22. Kuwait: Islamic Organization for Medical Sciences.

Sālūs, Ahmad 'Alī. 2008. Mawsū'at al-qadāya al-fiqhiyya al-mu'āsira wa al-iqtisād al-Islāmī [The encyclopedia of contemporary juristic issues and the İslamic economics]. Beirut: Mu'assasat al-Rayyān.

Sānū, Quṭb Muștafā. 2006. Al-Ijtihāed al-jamāè al-manshūd fì daw' al-wāqic al-mu'āsir [The pursued collective independent legal reasoning in light of the contemporary reality]. Beirut: Dār al-Nafā’is.

Sharaf, Sậlih Mūsā. 1985. Bad' hayāt al-insān fì daw' al-Qur'ān al-Karīm wa al-Sunna alNabawiyya [The beginning of human life from the perspective of the Glorious Qur'ān and the Prophetic Sunna]. In Al-hayāh al-insāniyya: bidāyatuhā wa nihāyatuhā fì al-mafhūm al-Islämī [Human life: its beginning and its end from an Islamic perspective], eds. Khālid al-Madhkūr, 'Alī Sayf, Ahmad Rajā̄̄i al-Jundī, and 'Abd al-Sattār Abū Ghudda, 182-88. Kuwait: Islamic Organization for Medical Sciences.

Yaseen, Mohammad Naeem. 1990. The Inception of Human Life in the Light of Statements of the Holy Qur'an and Sunnah and the Opinions of Muslim Scholars. Journal of Islamic Medical Association of North America 22: 159-67.

Yāsīn, Muhammad Na īm. 1985. Bidāyat al-hayāh al-insāniyya fì daw' al-nusūs al-shar iyya wa ijtihādāt 'ulamā' al-musliminn [The beginning of human life in the light of the religious texts and the interpretations of Muslim scholars]. In Al-hayāh al-insāniyya: bidāyatuhā wa nihāyatuhā fì al-mafh ūm al-Islāmī [Human life: its beginning and its end from an Islamic perspective], eds. Khālid al-Madhkūr, 'Alī Sayf, Ahmad Rajāī̄ al-Jundī, and 'Abd al-Sattār Abū Ghudda, 87-108. Kuwait: Islamic Organization for Medical Sciences.

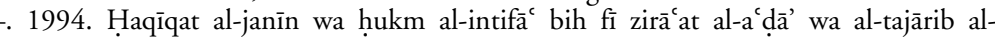
ilmiyya [The true essence of the embryo and the ruling on benefiting from it for organ transplantation and scientific experiments]. In Ru'ya Islämiyya li zirāa $\bar{c}^{c} b a^{c} d$ al$a^{\prime}$ 'd $\vec{a}$ 'al-bashariyya [An Islamic vision of transplanting some human organs], ed. Ahmad Rajāì al-Jundī, 277-374. Kuwait: Islamic Organization for Medical Sciences. 